NBER WORKING PAPER SERIES

\title{
CEO INVESTMENT CYCLES
}

\author{
Yihui Pan \\ Tracy Yue Wang \\ Michael S. Weisbach \\ Working Paper 19330 \\ http://www.nber.org/papers/w19330
}

\section{NATIONAL BUREAU OF ECONOMIC RESEARCH \\ 1050 Massachusetts Avenue \\ Cambridge, MA 02138}

August 2013

We would like to thank Shan Ge and Jongsik Park for excellent research assistance and Murillo Campello, Sergey Chernenko, Charlie Hadlock, Brandon Julio, Kathy Kahle and seminar participants in the 2013 China International Conference on Finance for helpful comments on an earlier draft. The views expressed herein are those of the authors and do not necessarily reflect the views of the National Bureau of Economic Research.

NBER working papers are circulated for discussion and comment purposes. They have not been peerreviewed or been subject to the review by the NBER Board of Directors that accompanies official NBER publications.

(C) 2013 by Yihui Pan, Tracy Yue Wang, and Michael S. Weisbach. All rights reserved. Short sections of text, not to exceed two paragraphs, may be quoted without explicit permission provided that full credit, including $(\subset$ notice, is given to the source. 
CEO Investment Cycles

Yihui Pan, Tracy Yue Wang, and Michael S. Weisbach

NBER Working Paper No. 19330

August 2013

JEL No. G32,G34,M12,M51

\begin{abstract}
$\underline{\text { ABSTRACT }}$
This paper documents the existence of a CEO Investment Cycle, in which firms disinvest early in a CEO's tenure and increase investment subsequently, leading to "cyclical" firm growth in assets as well as in employment over CEO tenure. The CEO investment cycle occurs for both firings and non-performance related CEO turnovers, and for CEOs with different relationships with the firm prior to becoming CEO. The magnitude of the CEO cycle is substantial: The estimated difference in investment rate between the first three years of a CEO's tenure and subsequent years is approximately 6 to 8 percentage points, which is of the same order of magnitude as the differences caused by other factors known to affect investment, such as business cycles or financial constraints. We present a variety of tests suggesting that this investment cycle is best explained by a combination of agency-based theories: Early in his tenure the CEO disinvests poorly performing assets that his predecessor established and was unwilling to give up on. Subsequently, the CEO overinvests when he gains more control over his board. There is no evidence that the investment cycles occur because of shifting CEO skill or productivity shocks. Overall, the results imply that public corporations' investments deviate substantially from the first-best, and that governance-related factors internal to the firm are as important as economy-wide factors in explaining firms' investments.
\end{abstract}

Yihui Pan

Department of Finance

1655 Campus Center Drive

University of Utah

Salt Lake City, UT 84112-9303

Yihui.Pan@business.utah.edu

Tracy Yue Wang

Carlson School of Management

University of Minnesota

321 19th Avenue South

Minneapolis, MN 55455

wangx684@umn.edu

\author{
Michael S. Weisbach \\ Department of Finance \\ Fisher College of Business \\ Ohio State University \\ 2100 Neil Ave. \\ Columbus, $\mathrm{OH} 43210$ \\ and NBER \\ weisbach.2@osu.edu
}




\section{Introduction}

Much of what we study in business schools concerns the role of the CEO and his management team. Yet, there is still substantial uncertainty about the right economic model for understanding the role of the CEO. The literature has adopted a variety of viewpoints, ranging from a first-best world in which the CEO always picks value-maximizing projects, to a principal-agent framework that allows for a variety of types of agency concerns. ${ }^{1}$ It is unclear what is the right way to view the role of CEOs in firms, or even how one would go about addressing this issue. Moreover, while the popular press typically ascribes many important actions firms take to CEOs, it is difficult to verify systematically the extent to which top management actually matters.

One way to measure the extent to which CEOs make a difference is to estimate the way in which firms' activities vary over their time in office. While there are numerous measurable and unmeasurable differences across CEOs and firms, a CEO's incentives and power inside the firm are likely to vary systematically over his career, so systematic differences in firm behavior over CEO tenure are likely to reflect the effects of the CEO's incentives and power. In this paper, we document striking patterns in corporate investment and disinvestment activities over the "CEO cycle" in a large sample of publicly traded U.S. firms. Disinvestments are fairly common in the early years of a CEO's tenure and decrease over time. Investments, on the other hand, are relatively low in the early years of a CEO's tenure and increase over time. The overall effect is "cyclical" firm growth in assets as well as in employment over CEO tenure, with the firm growth rate being lower in early years of a CEO's tenure than in his later years.

We estimate the magnitude of the CEO cycle in terms of the differences in disinvestment, investment, and firm growth, between the first three years of a CEO's tenure and the later years, holding other factors constant. The magnitude of the changes in firm investment and growth over the CEO cycle

\footnotetext{
${ }^{1}$ In the literature on principal-agent problems, CEOs have been accused of providing too little effort, overinvesting, underinvesting, enjoying the "quiet life", investing the firm's assets in projects that maximize their own human capital, delaying recognition of mistakes, building empires that maximize their utility rather than firm value, etc. See Jensen and Murphy (1990), Jensen and Meckling (1976), Myers (1977), Bertrand and Mullinathan (2003), Shleifer and Vishny (1989), Kanodia et al. (1989), Boot (1992), Demsetz and Lehn (1985), Yermack (1999), and Bebchuk and Fried (2004).
} 
is substantial. For example, the annual investment rate (investment-to-capital-stock ratio) tends to be 6 to 8 percentage points lower and the asset growth rate tends to be 3.2 percentage points lower in the first three years of a CEO's tenure than in his later years in office. Given that the median investment rate in our sample is $24 \%$ and the median asset growth rate is $7.6 \%$, the differences in investment and growth between the earlier and the later parts of the CEO cycle are clearly non-trivial. The effect of CEO cycle on investment is also of the same order of magnitude as the effects of other factors known to influence investment such as the business cycle, political uncertainty, and financial constraints.

Our estimates of the changes in investment with CEO tenure are robust to alternative ways of measuring corporate investment and disinvestment. To measure disinvestment, we consider the likelihood of asset sales, discontinued operations, or the combination of both. To measure investment, we consider the values of both acquisitions and capital expenditures. We find that both disinvestment and investment vary systematically over the CEO cycle regardless of the way we measure them, using information from firm-level financial statements, corporate announcements, acquisition data, or segment level data. The CEO investment cycles are present regardless of the reason for the CEO turnover (e.g., forced turnovers vs. exogenous turnovers due to death, illness, or retirement of the departing CEOs), CEO background (e.g., insider vs. outsider), time in office, and the industry conditions at the time of turnover. The existence of the CEO investment cycle regardless of the circumstances under which the incoming CEO takes office or his background suggests that this cyclical behavior of investment is a general phenomenon in publicly traded corporations.

We argue that the cyclical behavior of investment over CEO tenure is best understood through a combination of agency explanations. First, when a CEO takes office, he will have incentives to divest poorly performing assets that the previous CEO established and was unwilling to abandon (e.g., Boot (1992)). Second, for many reasons, CEOs usually prefer their firms to grow, potentially at the expense of shareholder value maximization. The board of directors is an important constraint on CEOs' ability to deviate from the shareholders' interest. However, as the CEO becomes more powerful in the firm over time, he will have more sway over his board and will be able to undertake investments that maximize his 
utility, potentially at the expense of value. Eventually, when the CEO steps down, the process is repeated by the next CEO.

We test a number of predictions of this agency explanation of the CEO investment cycle. First, if the incremental disinvestments early in a CEO's career reflect bad decisions made by the outgoing $\mathrm{CEO} /$ management, then the performance of disinvested assets should be poor. Using segment-level data we document that the unusually large disinvestment rate in the first three years of a CEO's tenure is made up of segments established by the previous CEO and in the bottom $10 \%$ of the distribution when ranked in terms of operating performance. Second, the residual influence from the old management should negatively affect the post-turnover disinvestment intensity. Our estimates indicate that the tendency of CEOs to disinvest poorly performing assets acquired by their predecessors is lower when the incoming CEO had a role in the outgoing management or if the prior management maintains a strong presence on the board of directors after turnover.

Third, since an uncaptured board of directors is an important factor that limits the CEO's ability to overinvest, the agency explanation for increasing investment with CEO tenure implies that more direct measures of the CEO's control over the board should be more important at explaining the investment increases than the CEO's tenure in office. We measure the CEO's capture of the board by the fraction of the board that is appointed during his tenure, and find that the increasing CEO influence on the board over his tenure explains the positive relation between CEO tenure and investment. Using exogenous variation in director turnover due to director retirement, we link the CEO's growing capture of the board to the increase of corporate investment over CEO tenure. In addition, we find that the quality of a firm's investments, measured by the market reaction to acquisition announcements, decreases with CEO tenure and becomes negative during the later portion of his time in office. The deteriorating investment quality is also related to the CEO's control of the board. These findings suggest that the increases in quantity and decreases in the quality of investments over the CEO cycle occur because the CEO acquires more control over his board over time. 
An alternative way of interpreting the relation between CEO tenure and firms' investments is that for some reason, changes in investment are efficient at all times. These changes in investment could be efficient if investment opportunities improve over CEO tenure, or if the change in assets is a function of differing skills of outgoing and incoming CEOs.

We perform a number of tests to evaluate these efficiency-based explanations for the CEO investment cycle. First, we document that the disinvestment and investment patterns hold even following exogenous turnovers due to death, illness or retirement of the departing CEOs, so it is unlikely that the cycles occur because of nonrandom timing of CEO turnovers. In addition, the investment patterns are unrelated to measures of exogenous productivity shocks. Further, investment quality deteriorates over the CEO tenure, suggesting that the increase in the quantity of investments occurs because of more valuedestroying investments rather than improved investment opportunities. Finally, we consider the possibility that changes in investment policy around turnovers could reflect an effort to improve the quality of the match between the new CEO's skills and firm assets. We find that the magnitudes of the CEO investment cycles are similar in situations in which the new CEO's skills are likely to fit the firm's asset structure (e.g., when single-segment firms hire an insider CEO) and in situations in which they potentially do not (e.g., in multi-divisional firms). Consequently, we conclude that the CEO investment cycles are better explained by a combination of agency problems than by the efficiency views.

The existence of an economically meaningful CEO investment cycle occurring for agency-related reasons has a number of important implications. First, there has been much work on external factors that affect investment, such as the business cycle, political uncertainty, and conditions of the financial markets. Our results suggest that governance-related factors internal to the firm are likely to be equally important. Second, the existence of the CEO investment cycle together with the additional tests presented in this paper suggests that investment in publicly-traded corporations deviates from the first-best level in important ways. Movement towards the first-best investment is likely one reason why private equity partnerships can pay large premiums to acquire public companies and nonetheless offer high returns to their investors. Third, our results provide insights on the types of agency problems that affect firms' 
investment decisions; they suggest that the empire-building preference plus the unwillingness to reoptimize on past investment decisions are important factors leading to investment inefficiencies in public companies. Fourth, the results imply that a policy of regular management turnover in public corporations potentially can be valuable. Such a policy will likely minimize overinvestment resulting from a CEO's growing capture of his board, and facilitate correction of errors he is unwilling to acknowledge. Finally, given the recent asset pricing literature suggesting that investment is a determinant of expected equity returns, our results imply that expected equity returns potentially vary systematically over the CEO cycle.

More broadly, this study contributes to the on-going debate about whether managers have systematic influences on firm policies and firm value, and more generally the implication for the role of management in the firm. Particularly important related work is the literature on whether CEO-specific styles affect firm policies (see Bertrand and Schoar (2003), Cunha and Ribas (2012) and Fee, Hadlock and Pierce (2013)). The literature also draws inferences about the value impact of CEO based on rare events such as CEO death (Johnson et al 1985, Bennedsen et al. 2007) and hospitalization (Bennedsen et al. 2012). Using an approach based on systematic changes in stock return volatility after the CEO takes office, Pan, Wang, and Weisbach (2013) estimate that CEOs contribute a nontrival amount to firm values. Documenting the way in which firm policies vary over the CEO cycle also offers an alternative way of identifying potential systematic managerial effects.

Using an earlier sample, Murphy and Zimmerman (1993) document systematic changes in a number of accounting variables around CEO turnover. These authors argue that changes around turnovers are mainly driven by poor firm performance. Another closely related study is Weisbach (1995), who considers a sample of large acquisitions, and finds that the likelihood of divestitures of poorly performing deals to be unusually high immediately following CEO turnover. ${ }^{2}$ Our study complements these earlier studies, documenting systematic patterns in disinvestment and investment over the CEO cycle, and providing additional evidence on the reasons for this cycle.

\footnotetext{
${ }^{2}$ Our paper shows that this effect holds using a much larger sample of turnovers and investments; even though it was an abnormally high rate of divestitures, Weisbach (1995) had only 10 deals that were divested subsequent to turnovers (see Table 7 of Weisbach (1995)).
} 
The remainder of the paper is structured as follows: Section 2 describes the data sources and the variables of interest. Section 3 establishes patterns of disinvestment, investment, and growth over the CEO cycle, and compares the magnitude of the investment changes over the CEO cycle with other factors that are well known to affect investment. Section 4 discusses potential explanations for the CEO investment cycle, while Section 5 conducts a series of tests of the implications of these explanations. Section 6 summarizes the findings and discusses their implications.

\section{Data}

\subsection{CEO Turnover and Tenure}

Our sample includes 5,420 CEOs that take office in 2,991 firms between 1980 and 2009. We identify CEOs based on the information in the ЕхесиСотр database. We use the information on job title, the year becoming CEO, and the CEO annual flag provided in ExecuComp to identify CEOs at the firmyear level. For each firm, we compare the designated CEO in each fiscal year with the CEO in the previous year to identify whether there is a CEO turnover in that year. Panel A of Table 1 describes the distribution of turnovers over time. Although ExecComp's coverage starts in 1992, some of the CEOs in the database took office before 1992, leading to some CEO turnovers from the 1980s being in our sample.

For each new CEO, the variable "Tenure" equals 0 for the fiscal year in which the CEO takes office, and increases with each year the CEO is in office. Panel B of Table 1 shows that the median CEO in our sample spends six years (including the turnover year) in office, and the average CEO tenure length is about seven years. Panel B also reports the distribution of CEO age at the time of turnover. Both the average and the median CEO age at turnover are 51.

We classify CEOs based on their experience with the firm. Using information on the time of a CEO "joining company" from ExecuComp, supplemented by the data on "starting job" from Boardex, we classify CEOs who have been with the firm for less than three years when becoming CEO as outsider CEOs, and the rest as insider CEOs. Based on this classification, about $32 \%$ of new CEOs in our sample 
are considered as outsider CEOs. This fraction is consistent with those reported in other studies such as Parrino (1997), Murphy and Zabojnik (2007), and Cremers and Grinstein (2011).

Since the purpose of our empirical work is to study the dynamics of firm investment and disinvestment activities over the CEO tenure, it is important to know the reasons for the initial CEO turnover. Unfortunately, firms are generally secretive about the true reasons for CEO changes. It is possible, however, to classify a relatively small subset of turnovers as either exogenously occurring, or forced. We follow Fee et al. (2013) and use the Factiva news search to identify CEO departures due to health issues and deaths. We classify turnovers as retirement-related if the departing CEO is older than 65. We consider turnovers caused by illness, death, or retirement of the departing CEOs to be exogenous turnovers. We also use the Factiva news search approach to determine whether a turnover is overtly forced (e.g., forced to leave or left under pressure). ${ }^{3}$ Through this process, we end up with 497 exogenous turnovers ( $9 \%$ of the sample), 96 of which were related to health issues and deaths, and 318 overtly forced turnovers (about $6 \%$ of the sample).

\subsection{Corporate Disinvestment}

To identify the probability as well as the intensity of corporate disinvestment activities in a given fiscal year, we use data on both discontinued operations from COMPUSTAT and asset sales from SDC Platinum Mergers \& Acquisitions Database. We consider the firm to have discontinued operations (" $I_{\{\text {discontinued operations }>0\}} "=1$ ) if the firm reports income or loss from discontinued operations ( "DO" in COMPUSTAT), and asset sales ("I $\left\{_{\{\text {asset sales }>0\}}\right.$ " $=1$ ) if the firm is indicated by SDC as the target company in transactions of "Acquisitions of Assets" or "Acquisitions of certain Assets". Panel C of Table 1 reports that about $9 \%$ of the firm-year observations have asset sales, and about $16 \%$ of the firm-year observations have discontinued operations, and $21 \%$ of the firm-year observations have at least one of these types of disinvestment activities. The correlation between these two types of disinvestment activities is 0.22 .

\footnotetext{
${ }^{3}$ We thank Edward Fee, Charles Hadlock, and Joshua Pierce for kindly providing us with their classification of turnovers.
} 
An alternative way to identify disinvestment activities is to use corporate announcements. The announcement information is obtained from the "Key Developments" database from the Capital IQ database (coverage starting from 2001): "Event 1" contains announcements of "Seeking to Sell/Divest" and "Event 21" captures announcements related to "Discontinued Operation/Downsizing". ${ }^{4}$ Based on the announcement date of each event provided by Capital IQ, we define a monthly disinvestment indicator variable $I_{\{\text {downsizing announcement(s) in the month }\}}$ that equals one if the company announces either Event 1 or Event 21 or both in a month. Panel $\mathrm{C}$ of Table 1 documents that $4 \%$ of firm-months contain disinvestment announcements.

Further, we use information from COMPUSTAT "historical segment" data to measure the divestiture or discontinuation of previous investments at the segment level. We start with all operating/business segments with positive sales over the sample period, and track them through time using the unique segment ID provided by COMPUSTAT. We identify divestitures or discontinuations of segments $\left(I_{\{\text {segment termination }\}}=1\right)$ when a distinct segment ID disappears in a particular year and does not reappear in the sample subsequently. About $10 \%$ of segments are disinvested/discontinued in any given year during our sample. We measure segment performance with segment-year level operating profit/loss scaled by sales.

To measure the magnitude of disinvestment, we need information about both the value of asset sales and the value of discontinued operations. The value of asset sales is obtained from the transaction value of the asset acquisition deals from SDC. The value of discontinued operations is less straightforward because there is no single item in the financial statements containing that information. If the discontinuation of operations is planned but not implemented in a given year, then the firm reports the estimated liquidation value of the discontinued operations in the balance sheet ("ACDO" in COMPUSTAT for discontinued current assets and "ALDO" for discontinued long-term assets). If the discontinuation of operations is planned and implemented in the same year, then the liquidation value will

\footnotetext{
${ }^{4}$ Both Event 1 and Event 21 appear to capture ongoing or intended disinvestment activities. Sample headlines for these events: "ADC Telecommunications to close LeSueur facility"; "BSQUARE Corp. intends to close its information division in San Diego".
} 
be reported as the sales of property, plant, and equipment in the cash flow statement ("SPPE" in COMPUSTAT). There are some firm-year observations in which the firm reports income from discontinued operations, but there is no information in the balance sheet or the cash flow statement to estimate the value of the discontinued operations. In those cases, we use the income from the discontinued operations as a proxy for the value, assuming that the value should be at least equal to the liquidating income generated by the discontinued operations. In summary, the value of discontinued operations is calculated as the maximum value among the sales of PPE, assets of discontinued operations, and the income from discontinued operations.

We calculate the disinvestment rate as the sum of the value of asset sales and the value of discontinued operations divided by the net value of the firm's property, plants, and equipment at the beginning of the year. Panel $\mathrm{C}$ of Table 1 documents that the average disinvestment rate in our sample is 4.1\%. However, if we condition on disinvestment occurring in a year, then the average disinvestment rate is $23.2 \%$, which is close to the median investment rate of $23.9 \%$.

Since disinvestment is often accompanied by substantial restructuring costs, we also construct the restructuring rate, which is the absolute value of the pre-tax restructuring cost ("RCP" in COMPUSTAT) divided by the net value of the firm's property, plant, and equipment at the beginning of the year. These costs are related to disinvestments and usually a one-time expenditure, including expenses related to plant closure, impairments, severance, related benefit costs, and other exit costs. Panel C of Table 1 documents that the average restructuring cost equals $2.3 \%$ of the firm's capital stock. It is $8.5 \%$ of capital stock if we condition on restructuring happening.

\subsection{Corporate Investment}

We consider two major forms of corporate investment: capital expenditures and acquisitions. Since firms always have some investment in every year, we do not focus on identifying the existence of investment, but instead focus on its magnitude. We define Capx Rate as capital expenditures scaled by the net value of the firm's property, plants, and equipment at the beginning of the year, and Acquisition Rate as the value of acquisitions scaled by the net value of the firm's property, plants, and equipment at the 
beginning of the year. Acquisitions include completed deals covered in the SDC database, either acquisition of assets or equity interests. Investment Rate is defined to be the sum of Capx Rate and Acquisition Rate. Panel C of Table 1 shows that the investment rates are skewed, since the average Capx Rate is $33 \%$, and the median is $20 \%$. The average Acquisition Rate is $34 \%$, and the median is $0 \%$. The average total Investment Rate is $72 \%$, and the median is $24 \%$.

We also examine the intensity of corporate announcements about expansion or acquisition over CEO tenure. The business expansion news includes "Event 3" ("Seeking Acquisitions/ Investment") or "Event 31" ("Business Expansion") from the "Key Developments" database from Capital IQ. We further augment these announcements with the acquisition announcements from the SDC Platinum. For each sample firm, we identify both domestic and international acquisitions with disclosed transaction values above $\$ 1$ million, over the sample period. We exclude leveraged buyouts, exchange offers, repurchases, spinoffs, minority stake purchases, recapitalizations, self-tenders, and privatizations. Based on the announcement date of each event, we define a monthly investment indicator variable $I_{\{\text {investment announcement(s) }}$ in the month\} that equals one if the company has either expansion or acquisition announcements in the month. Panel $\mathrm{C}$ of Table 1 documents that $8 \%$ of firm-months contain investment announcements.

Further, we identify new business units by examining whether a new segment ID appears in a given year (provided it is not the first year the company appears in the segment data base) and exists for at least 2 years. About $16 \%$ of segment-years are of new segments using this classification.

We also measure the combined effect of disinvestment and investment on a firm. Since both disinvestment and investment can affect the size of the firm's physical asset and labor, we construct Asset Growth Rate as the annual growth rate of the firm's book assets and Employment Growth Rate as the annual growth rate in the number of employees. The average Asset Growth Rate is about 20\%, although the median is only $7.6 \%$. The average Employment Growth Rate is $9.4 \%$, and the median is $3 \%$. All variables on disinvestment, investment, asset and employment growth rates are winsorized at the top and bottom $1 \%$ of the distribution.

\subsection{Other Firm Characteristics}


To control for other factors that potentially affect investment or disinvestment intensity, we also include a set of firm characteristics in our econometric specifications. Panel D of Table 1 contains summary statistics of these variables. The average firm in our sample is about 19 years old, has book assets of about $\$ 1.2$ billion, 24\% leverage (the sum of long-term debt and short-term debt divided by total assets), and market equity to book equity ratio (MB) 2.9. The average industry-adjusted ROA is $5.7 \%$ (median 3.3\%), and the average industry-adjusted stock return is $14.7 \%$ (median is $3.9 \%$ ). Slightly more than half of the firms pay dividends. The average industry-adjusted performance measures are different from zero because we construct the industry averages using the COMPUSTAT universe, not just our sample firms. All control variables are winsorized at the top and bottom $1 \%$ of the distribution. Appendix A presents definitions of all variables.

\section{Measuring the CEO Investment Cycle}

There are two main components of the CEO investment cycle: high disinvestment after turnover and increasing investment subsequently. We first consider the relations between disinvestment and investment with the cycle separately, and then examine their combined effect on the firm's asset and employment growth over the CEO cycle.

\subsection{Disinvestment and CEO Tenure}

Panel A of Table 2 reports the probability of disinvestment by tenure years 0 to 8 subsequent to the turnover for both the full CEO sample and the subsample of exogenous turnovers, and for different types of disinvestment (asset sales and discontinued operations). In the full sample, the likelihood of disinvestment peaks in year 1 (the year after the turnover) at $21.2 \%$, and then it monotonically decreases over the CEO tenure. By year 8 , the likelihood of disinvestment decreases to $13.7 \%$, a $36 \%$ reduction relative to year 1 . The same pattern exists after exogenous turnovers, and the drop in disinvestment probabilities is even sharper for this subsample (from $27 \%$ in year 1 to $13 \%$ in year 8 ). This result suggests that high post-turnover disinvestment intensity does not just occur after forced turnovers, but 
instead occurs following all turnovers. In addition, the decline in disinvestment with CEO tenure occurs for both asset sales and discontinued operations.

Panel B of Table 2 presents estimates of multivariate equations predicting the likelihood of disinvestment as a function of CEO tenure, controlling for the CEO's age, ${ }^{5}$ the firm's age, relevant firm characteristics, as well as firm and year fixed effects. "Tenure (in years)" counts the CEO's time in office up to the year of the observation. The estimates presented in Column (1) indicate that in the full sample, the disinvestment likelihood decreases by 0.5 percentage points per year of CEO tenure. The estimated per-year decline is small because it is the average over the entire tenure length, including some CEOs who stay on the job for very long periods (e.g., more than 10 years).

One possible concern in interpreting the estimates in Column (1) is that the decline is driven by the outgoing CEOs being fired. For this reason, in Column (2) we only include CEOs with total tenure length greater than six years (the median of the sample distribution), and examine the pattern of disinvestment in the first five years of their tenure. The estimates in this subsample imply a sharper decline in disinvestment probabilities with tenure, with the disinvestment probability decreasing by 1.7 percentage points per year during the first five years. The difference in estimated coefficients between Columns (1) and (2) likely comes from the fact that most disinvestments likely occur during the early period of a CEO's tenure.

In Columns (3)-(8), instead of using a linear function of tenure, we create an indicator variable that equals one for the first three years of a CEO's tenure (i.e., years $0,1,2$ ). The coefficient of this variable provides an estimate of the average difference in the disinvestment probability between the first three years and the rest of the CEO's tenure. The coefficient estimates for the full sample indicates that the annual disinvestment probability is 3.2 percentage points higher in the first three years than in the rest of the tenure. The same pattern holds in subsamples of more recent turnovers (since 1990), in long-term CEOs with at least six years of tenure, after insider successions, exogenous turnovers, and forced

\footnotetext{
${ }^{5}$ See Yim (2013) and Li, Low and Makhija (2011) for the estimates of the way in which CEO age affects corporate investment.
} 
turnovers. The largest difference in disinvestment probabilities over time is for forced turnovers (5 percentage points higher). However, the results in Panel B of Table 2 indicate that there also is a decline in disinvestment probabilities following other subsamples of turnovers.

We next estimate the likelihood of corporate disinvestment using two different data sources: corporate news announcements and segment termination. When using news announcements, since we know the month in which the news is announced, we construct monthly rather than annual data, and generate an indicator variable that equals one for a CEO's first 24 months in office. The results, presented in Columns (1) and (2) of Panel C of Table 2, confirm those presented in Panel B using annual accounting data. They indicate that the likelihood of a company announcing a disinvestment in a particular month is about 1 percentage point higher on average in the first 24 months than during the rest of the tenure. This effect is relatively large, given the announcement probability of $4 \%$ (per month) in our sample. The same pattern holds after exogenous turnovers as well.

In Columns (3) and (4) of Panel C of Table 2, we estimate the likelihood that a segment is terminated in a particular year. In these equations, the unit of observation is a segment-year, and the dependent variable is an indicator variable that equals 1 if a segment is terminated in a particular year. In addition to firm-level controls, we also include a set of segment-level controls such as a measure of segment performance (whether the segment operating profit/loss over sales is below the bottom 10\% ($7.4 \%$ ) of the sample distribution), the number of segments in the firm, and the segment age. Consistent with the earlier findings, the results using both the full sample and the subsample of exogenous turnovers suggest that the probability of terminating a segment is significantly higher in the early years of a CEO's tenure than in his later years. Overall, the results in Panels B and C of Table 2 use three different sources of data for measuring disinvestment, yet yield consistent results; each suggests that the likelihood of disinvestment is substantially higher immediately following a CEO turnover.

In Panel D of Table 2, we present the average magnitude of disinvestment over CEO tenure. Annual disinvestment averages $4.7 \%$ of the firm's total capital stock during the first three years of CEO tenure, and then declines over time. Cumulatively, disinvestment equals $14.1 \%$ of the firm's total capital 
stock in the first three years, clearly a non-trivial quantity. Following exogenous turnovers, the disinvestment rate first increases but eventually declines substantially after year 4 . The cumulative quantity of disinvestment in the first three years is $14.8 \%$, comparable to that in the full sample. Column (3) reports the disinvestment rate over tenure conditional on disinvestment occurring. Interestingly, the declining trend largely flattens out, suggesting that the decline in the magnitude of disinvestment over tenure is mainly driven by the decline in the disinvestment probability rather than a decreasing trend in the size of the disinvested assets. Finally, we also report the trend of restructuring rate, which equals the ratio of restructuring expenses over capital stock. Again, restructuring rate starts around 3\% and declines over time, consistent with the pattern in disinvestment rate.

In summary, the results in Table 2 document a strong negative relation between a CEO's tenure and the firm's disinvestment: disinvestment intensity is substantially higher at the beginning of a CEO's tenure than later in his career. This disinvestment cycle exists after exogenously occurring turnovers as well as forced turnovers. Further, since CEO tenure is correlated but not perfectly collinear with firm age or CEO age, we are able to differentiate the CEO tenure cycle effect from the firm's life cycle effect and the CEO's personal life cycle effect by controlling for firm age and CEO age.

\subsection{Investment and CEO Tenure}

We now consider the way in which corporate investment varies with CEO tenure. Panel A of Table 3 reports the average investment rate by tenure year for both the full CEO sample and the subsample of exogenous turnovers, and for total investment as well as its components: capital expenditures and acquisitions. In each case, there is an increasing trend in investment over CEO tenure. The total investment rate, which is defined as the sum of capital expenditures and acquisition values divided by the lagged capital stock, increases from $53 \%$ in year 0 to $75 \%$ in year 8 , a $40 \%$ increase. A large part of the increase comes from the increasing acquisition rate over tenure, since the acquisition rate almost doubles between year 0 and year 8 . The investment rate, both in terms of acquisitions and capital expenditures, also increases after exogenous turnovers, although the magnitude of the increase is smaller than in the full sample. 
In Panel B of Table 3, we estimate equations predicting the investment rate as a function of CEO tenure, controlling for firm characteristics that potentially affect investment. We first include tenure linearly and predict investment, using the full sample in Column (1) and the first 5 years for CEOs that stayed on the job for at least 6 years in Column (2). In each case, the coefficient on tenure is positive and statistically significant, implying that investment increases over the CEO's tenure. As in the comparable equations predicting disinvestment (Panel B of Table 2), the coefficient is substantially larger when we restrict the sample to CEOs with tenure of 5 years or fewer, suggesting that most of the effect of tenure on investment occurs shortly after a CEO takes office.

Columns (3) - (8) of Table 3 present estimates of specifications using a dummy variable that indicates whether the CEO is in his first three years. Columns (3) and (4) present estimates for the full sample and find that the investment rate tends to be 6 to 8 percentage points lower in the first three years of a CEO's tenure than in his later years in office. If we take the median investment rate in our sample $(24 \%)$ as the "normal" rate, then the results imply that the investment rate tends to be 25 to $33 \%$ lower than the normal rate in the early years of a CEO's tenure. Columns (5) - (8) present estimates of this equation for various subsamples: Long-Term CEOs (greater than 6 years), insider successions, exogenous turnovers, and forced turnovers. The difference in the investment rate between earlier and later tenure years is most dramatic after forced turnovers $(12.4 \%)$, but is also substantial after insider successions (4.3\%). These findings suggest that the phenomenon of investment increasing over the CEO cycle is a general one, and not exclusive to certain types of turnovers or CEOs.

Panel $\mathrm{C}$ of Table 3 considers the intensity of business expansion and acquisition related news announcements and the establishment of new segments over CEO tenure. Consistent with the increasing investment rate over tenure documented in Panels A and B, we find that the probability of an expansion or acquisition related corporate news and the probability of starting a new segment are also significantly 
higher in a CEO's later years in office than in the first three years, both in the full sample and after exogenous turnovers. ${ }^{6}$

An implication of changing investment and disinvestment behavior is that the firm's asset size should adjust to reflect both effects. Since investment and disinvestment move in the opposite directions over CEO tenure, we predict that, holding other factors constant, a firm's asset growth rate should increase with CEO tenure. We test this hypothesis in Panel A of Table 4, in which we report estimates of equations predicting the growth of a firm's assets using the same specification as before. In Panel B of Table 4, we report estimates of comparable equations predicting the growth of employment as a function of CEO tenure.

These estimates indicate that the asset growth rate is on average 3.2 percentage points lower and the employment growth rate is 2.2 percentage points lower in the first three years of CEO tenure than in later years. Given that the median asset growth rate is $7.6 \%$ and the median employment growth rate is $3 \%$, the difference in these growth rates over CEO tenure is clearly substantial. The behavior of the growth rates in assets and employment over the CEO cycle is likely reflective of the cyclical disinvestment and investment documented above.

\subsection{Benchmarking the Magnitude of the CEO Investment Cycle}

The CEO investment cycle leads to variation in investment likely caused by forces internal to the firm. As a benchmark to assess the magnitude of the CEO investment cycle, it is useful to compare its size to estimates of other factors that are known to affect investment. In particular, the literature has argued that external factors such as the business cycle, political uncertainty due to the election cycle and financial constraints during crisis periods can affect a firm's investment. Appendix B surveys estimates of the extent to which these factors affect investment. To estimate the effect of business cycles on investment, we reestimate equations from Tables 2-4, including an indicator variable for recession years. These estimates are presented in Appendix Table B1. For estimates of the effect of political uncertainty

\footnotetext{
${ }^{6}$ There was a change in how segments were reported in 1997-1999 (SFAS 131). This rule could potentially have led some firms to disaggregate segment data, which would have looked like an expansion in our specification. In unreported analysis, we exclude this period and obtain results similar to those reported here.
} 
on investment, we rely on Julio and Yook (2012), and for estimates of the effect of financial constraints on investment, on Ball, Hoberg and Maksimovic (2013). ${ }^{7}$

These estimates are summarized in Table 5. We estimate the magnitude of the CEO cycle in terms of the differences in the investment rate, between the first three years of a CEO's tenure and the later years, holding other factors constant. Because each of the comparison studies normalizes investment differently, we reestimate the CEO cycle effect using three different definitions of investment rate: capital expenditures over lagged PPE, or over lagged book assets, or over sales, and then compare the effect of the CEO cycle to these other factors. The numbers in Table 5 indicate that the incremental effect on investment from being in a CEO's first 3 years is approximately the same as being in recession or facing financial constraints, and more than twice the effect of being in an election year. These numbers suggest that the effect of the CEO investment cycle is substantial in magnitude, comparable to other factors that are commonly accepted to be important determinants of investment.

\section{Potential Reasons for the CEO Investment Cycle.}

We have documented that there is a CEO investment cycle, meaning that, holding other factors constant, disinvestment is relatively high early in a CEO's career, and investment increases with a CEO's tenure. Moreover, these effects appear to be quantitatively important, at least the same order of magnitude as factors commonly thought to be important drivers of corporate investment activity such as business cycles and financial constraints.

There are two types of explanations why CEO investment cycles could exist. The CEO cycle could reflect a combination of agency-based factors or, alternatively, it could occur because of efficiencybased reasons in which investment is always at the first best. In this section, we discuss potential

\footnotetext{
${ }^{7}$ Julio and Yook (2012) identify the effect of political uncertainty by comparing firms' investments in election and non-election years, holding other factors constant. Ball, Hoberg, and Maksimovic (2013) use a text-based approach to identify constrained firms, and then estimate the effect of these constraints on firms' investment. For more details, see Appendix B. A previous draft of this paper included estimates of increases to corporate income taxes on investment; we dropped this discussion because the estimates differed so dramatically. For example, contrast the very large estimates of taxes on investments in Summers et al. (1980) with the much smaller ones in Desai and Goolsbee (2004).
} 
explanations for the disinvestment and investment components of the CEO investment cycle, emphasizing testable implications from both agency and efficiency based theories.

\subsection{Reasons why we could observe disinvestment following CEO turnover.}

One reason why we could observe high disinvestment shortly after turnover is if post-turnover divestitures reflect incumbent CEOs' reluctance to divest bad investments that they have made, leading a new CEO to disinvest units that have performed poorly. There are several reasons why a CEO would knowingly hold onto poorly performing assets that they personally were responsible for acquiring or establishing. First, the CEO could extract private benefit from these assets at the expense of the shareholders. ${ }^{8}$ Second, a divestiture could be viewed as essentially an admission of mistake and reflects poorly on the CEO personally (e.g., Kanodia, Bushman, and Dickhaut (1989) and Boot (1992)). When management changes, the new managers do not necessarily enjoy the same private benefits from these assets and are less averse to admitting their predecessors' mistakes. Therefore, the new management is more likely to sell the assets if these assets are worth more to an outsider than to the firm. Based on this argument, post-turnover divestitures could occur even if the departing CEO is not fired. The argument that the high disinvestment rate following CEO turnover reflects sales of poorly performing assets that the previous management was unwilling to sell also has two additional testable implications:

Implication 1: Performance of divested assets. Given that the argument is the assets that are sold after turnover should have been sold by the prior management, the assets' performance should be abnormally low. The poor performance should be due to mismanagement or a bad fit with the firm rather than exogenous productivity shocks, which would presumably affect potential purchasers as well.

Implication 2: Influence of outgoing management. If the reason for the post-turnover divestitures is that management is unwilling to sell assets they were responsible for acquiring, then the influence the old management has on the new CEO after turnover should affect his willingness to sell the assets

\footnotetext{
${ }^{8}$ Discussion of private benefits of control goes back at least to Berle and Means (1932) and have become a key element of many models of corporate governance (see Tirole 2006, pp. 16-17 for example).
} 
subsequent to the turnover. Therefore, this argument predicts that when outgoing management has more influence on the new CEO, there should be fewer divestitures following CEO turnover.

In contrast to agency-based reasons, the model of Maksimovic and Phillips (2002) provides a skill-based explanation for the high disinvestment rate following management changes in which investment is always at the first-best level. In this model, conglomerate firms choose their asset structure based on the relative productivity of its business segments, which in turn depends on the CEO's relative skill in managing assets in different industries. In such a world, if the CEO changes and the incoming CEO has different skills from the outgoing one, then it is possible that the optimal set of assets the firm should own will change, leading to divestitures.

The skill-based arguments do not predict that divested units should have unusually bad performance, because the firm should be the optimal owner of the asset prior to the CEO change. Instead, these arguments imply that post-turnover divestitures reflect the change in the skills of the outgoing and incoming CEOs. Therefore, the prior performance of the divested assets provides a way in which we can distinguish between the explanations for the post-turnover disinvestment. Further, the Maksimovic and Phillips (2002) model also does not predict that the residual influence of the old CEO on the new CEO should matter for the firm's asset structure choice after the turnover. Instead, applying the Maksimovic and Phillips (2002) logic to CEO turnover has the following implication:

Implication 3: Fit of the new CEO's skill to firm assets. Holding other factors constant, the more that the new CEO's skills differ from the firm's current asset structure, the more divestitures will be observed after CEO turnover.

\subsection{Reasons why investment could increase with CEO tenure.}

For many reasons, CEOs usually prefer to grow their firms rather than to shrink them. CEOs' pay and prestige are generally positively correlated with firm size, adding units that diversify their firms can lower the risk of their financial positions and human capital, they can purchase "glamorous" divisions that are fun to manage, they can create new positions for favorite employees through growth, or they could 
have "hubris" and overestimate their ability to add value to a line of business. ${ }^{9}$ These arguments imply that a CEO's preferences for growth could differ from those of the shareholders. Consequently, the factors that constrain management from taking as many investments as it wants are important contractual elements of the firm. For example, Jensen (1986) focuses on the role of debt in constraining managers' propensity to overinvest. Another source of constraints on management's ability to invest as it chooses is the board of directors.

The board of directors is particularly relevant for understanding CEO investment cycles, since the CEO's influence over the board is likely to increase over time. As emphasized by Hermalin and Weisbach (1998), so long as a CEO is infra-marginal relative to a potential replacement, he will have some influence over the director selection process and will have incentives to use this influence to appoint directors who are less likely to oppose his will. Over time, boards will evolve towards ones that are loyal to the CEOs that appoint them, and thus less likely to constrain the CEOs from undertaking whichever investments they want. Therefore, the dynamics of the board and its loyalty to the CEO, together with the CEO's preference for investments even if they are not value-maximizing, could potentially lead to the increase in investment with CEO tenure that we document in Table 3.

Implication 4: CEO power and investment. Holding other factors constant, the increase in investment over CEO tenure should come through the CEO's control over the board of directors. Therefore, controls for the CEO's influence on the board should lessen the estimated effect of CEO tenure on investment. In addition, the agency argument predicts that the quality of firms' investments should decrease with the CEO's tenure.

In contrast to the agency arguments, the arguments based on the CEO's skill do not predict increasing investment over CEO tenure. They do predict that a new CEO will increase investment in segments that he has comparative advantage in managing, but there is no reason why the quantity of investment should increase and the quality decrease over his career.

\footnotetext{
${ }^{9}$ The literature arguing that managers tend to build "empires" is enormous and dates back to Baumol (1959), Marris (1964), Williamson (1964), and Donaldson (1984). See also Roll (1986), and Morck, Shleifer and Vishny (1990).
} 
However, there are also several other non-agency-based reasons that potentially explain the observed increase in investment over CEO tenure. First, the CEO's time in office could reflect the CEO's ability or the firm's prospects. The fact that a CEO has managed to stay in office for a longer period of time means that he was not fired early in his career, increasing the likelihood that the firm has done well during this time. Good performance potentially reflects better investment opportunities, which could lead to a positive correlation between tenure and the firm's investment rate. Second, there could be some learning by doing in a CEO's career, leading the CEO to be able to make more (and better) investments over time. Third, it is possible that investors are reluctant to provide capital to a firm for which they know little about the firm's new management, and such reluctance decreases as the CEO and his team stay in office for longer time. A way to differentiate these alternative explanations from the agency explanation described above is to examine the quality of the firm's investments over time: The agency explanation predicts that the firm's investment quality should decline over CEO tenure, while these alternative explanations predict that it should be increasing (or at least non-decreasing) with the CEO's tenure.

\section{Distinguishing between Explanations for CEO Investment Cycles}

This section distinguishes between the potential explanations for the observed CEO Investment Cycles. It does so by empirically evaluating the testable implications of each discussed in Section 4.

\subsection{Performance of Divested Assets}

To evaluate the performance of the divested assets, we rely on COMPUSTAT (historical) segment data, which offers two advantages over other potential data sources. First, the data allows us to identify the CEO and year when a segment is established and when it is divested or discontinued. Second, it allows us to capture industry- or firm-specific shocks that could affect disinvestment intensity by including segment-industry-year or firm-year fixed effects. The inclusion of these fixed effects implies that any measured segment underperformance does not occur because of industry-wide or firm-specific economic shocks, but instead reflects (idiosyncratic) decisions by the previous management. 
We estimate models that predict whether a particular segment is divested or discontinued in a given year. The agency explanation for disinvestment implies that the post-turnover divestiture is concentrated in assets with very poor performance, i.e., assets that likely reflect mismanagement by the prior leadership. Thus, we define "Underperforming Segment" as a segment whose lagged profitability is at the bottom $10 \%$ of the sample distribution. ${ }^{10}$ In addition, we define "Original CEO Replaced" as an indicator variable that equals one for all firm-year observations after the CEO who established the segment steps down. We use these two indicator variables as well as their interaction to predict the likelihood a given segment is terminated in a given year. Because the likelihood of termination is negatively related to the segment's age (see Table 2, Panel B), we include the segment's age in the specification as well. We control for segment industry or firm-specific shocks by including industry-year or firm-years fixed effects into each specification. This specification allows us to evaluate Implication 1, which suggests that the interaction term should have a positive predictive effect. In contrast, the skillbased arguments imply that the main predictive power should load on the direct effect of CEO turnover, and the interaction effect should be insignificant.

Panel A of Table 6 contains estimates of this equation both for the full sample and the subsample of exogenous turnovers. The results indicate that the effects of Original CEO Replaced and Underperforming Segment are small in magnitude and not statistically significant, while the coefficient of .073 on the interaction of the two variables is large and statistically significant. These estimates imply that CEO turnover facilitates the disinvestment of poorly performing units established by the previous leadership. Since we control for industry-specific shocks in Column (1) and firm-specific shocks Column (2), the poor segment performance likely reflects mismanagement by the previous leadership rather than exogenous shocks to segment productivity. The fact that it took a CEO change to induce the divestiture of a poorly performing segment implies that prior to the management change, the firm did not hold the optimal set of assets.

\footnotetext{
${ }^{10}$ The results are similar under different threshold choices such as the bottom $5 \%$ or bottom $15 \%$.
} 
Further, the insignificant and even negative coefficients on Original CEO Replaced together with a positive and significant interaction effect suggest that only substantially underperforming segments established by the previous management are divested at an abnormally high rate following CEO turnover. Consequently, post-turnover disinvestment does not appear to reflect the change in the CEOs' skill or their personal styles or preferences.

\subsection{The Influence of the Outgoing Management}

To evaluate Implication 2, we construct four measures of the residual influence of the previous CEO (or management) on the new CEO. We define "Old CEO Stays As Chairman" as a dummy variable equaling one if the outgoing CEO serves as the Chairman of the Board during the first year of the new CEO's tenure, "\% of Old Mgmt. On Board" as the fraction of the four most highly paid non-CEO executives under the previous management who sit on the board after turnover, "Outsider New CEO" as a dummy variable equaling one if the new CEO comes from outside the company, and "Staggered Board" as a dummy variable equaling one if the company has a staggered board. If a company has a staggered board, in most instances there are three classes of directors, with each class serving overlapping threeyear terms. With a staggered board, the new CEO's ability to change the composition of the board established under the previous regime during early years of his tenure is limited, because it would take at least two elections to replace a majority of the board. Moreover, whether the company has a staggered board is usually determined historically, rather than at the discretion of the current management. Thus, the cross-sectional variation in Staggered Board provides exogenous variation in the outgoing management's residual influence on the new CEO.

We estimate the extent to which these variables affect the likelihood that the underperforming segments established by the departing CEO get terminated in the first three years of the new CEO's tenure. Panel B of Table 6 reports estimates of these equations. In Column (1), the coefficient on the interaction between Old CEO Stay as Chairman and Underperforming Segment is -0.027 and is statistically significant. This result suggests that if the old CEO stays as the Chairman of the Board, then the likelihood of an underperforming segment established by the old CEO being divested in the first three 
years of the new CEO's tenure decreases by about 3 percentage points, a $23 \%$ reduction relative to when the old CEO does not stay $(0.115) .{ }^{11}$ While departing CEOs can certainly play an important advisory role when they are chairmen of the board, this finding suggests that there is also a negative side to this practice in that it can hinder error correction subsequent to CEO turnover.

Column (2) of Panel B shows that the more executives from the previous leadership remain on the board, the less disinvestment after the new CEO takes office. Column (3) shows that outsider CEOs are more likely to disinvest underperforming segments established by the predecessors shortly after turnover. Finally, Column (4) indicates that a classified board, which likely serves to perpetuate the influence of the outgoing management team, decreases the likelihood that a firm will disinvest a poorly

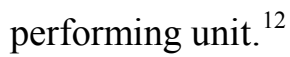

Overall, these results suggest that when the outgoing management team has a larger influence on the incoming team, there will be less disinvestment of poorly performing assets subsequent to the management change. These results are consistent with the view that the increase in disinvestment following management changes reflects the reluctance of previous management to divest projects for which they are personally responsible for undertaking.

\subsection{The Fit of the New CEO's Skills with the Firm's Assets}

Ideally, to test Implication 3 one should observe the incoming CEO's human capital and somehow measure the extent to which it fits with the firm's asset structure. However, such a measure requires detailed information about the CEO's background and its fit with the firm's assetso. Instead, our approach is to identify situations in which the CEO's skills likely fit (or not fit) the firm's assets, and compare the magnitude of the post-turnover disinvestment in these situations with that in the full sample.

\footnotetext{
${ }^{11}$ The direct effect of Underperforming Segment is larger than in the previous panel because this model is estimated using only the first three years of the new CEO's tenure, when disinvestment is most common.

${ }^{12}$ Of course, the decisions as to how many executives from the outgoing management team remain on the board, and whether the company chooses an outside CEO are all endogenously determined and are often related to firm performance. However, using the segment data allows us to control for industry and firm-specific performance shocks that could affect both the divestiture probability and the segment performance. Further, as we have discussed, the variation in old management's residual influence due to the variation in the existence of Staggered Board is likely unrelated to any decisions related to divestitures, and therefore is clearly exogenous.
} 
Unlike conglomerates, single-segment firms provide little opportunity for the new CEO to divest assets that do not match his skills. If a single-segment firm further hires a company insider or industry insider CEO who possesses firm- or industry-specific skills that already match the current assets, the need to change the asset structure to match the CEO's skills is likely to be minimal. Therefore, Implication 3 suggests that there should be less post-turnover disinvestment in single-segment firms and even less if these firms hire firm or industry insiders as CEOs.

We classify firms as single-segment firms using information in the COMPUSTAT historical segment database. Table 7 presents estimates of the basic equations from Tables 2 and 3 using the subsample of single-segment firms. The estimates in Columns (1) and (2) confirm significant CEO investment cycles, with an increase in disinvestment (mostly discontinued operations) in the early years of a CEO's tenure and an increase in investment in the later years. The magnitudes of these effects are comparable to those reported in Tables 2 and 3. Columns (3) and (4) further restrict the sample to be single-segment firms that hired company or industry insiders. ${ }^{13}$ The estimated magnitudes of the CEO investment cycles are similar to those in Columns (1) and (2) and to those in the full sample. The fact that the investment cycle is similar in the subsample of single-segment firms is inconsistent with Implication 3, and therefore inconsistent with the skill-based explanation for the CEO investment cycles.

Eisfeldt and Kuhnen (2013) could be considered as a special case of the Maksimovic and Phillips (2002) in which managerial turnovers are accompanied by significant changes in managerial skills. In this model, a shock to the productivity of physical capital may change the desired managerial skills, leading to management turnovers. This theory implies that CEO turnovers that follow significant industry productivity shocks are more likely to have incoming CEOs possessing very different skills from outgoing CEOs, and are also more likely to be followed by significant changes in investment and disinvestment. Consequently, this argument predicts that there should be larger CEO investment cycles when CEO turnovers follow industry shocks.

\footnotetext{
${ }^{13}$ Data on Industry insiders are provided on Camelia Kuhnen's website: http://www.kellogg.northwestern.edu/faculty/kuhnen/htm/RESEARCH/eisfeldt_kuhnen_CEO_turnover_data.txt
} 
However, this argument cannot explain the existence of the CEO investment cycles after exogenous CEO turnovers, which are unlikely to coincide with industry productivity shocks. We further provide direct tests of the impact of industry productivity shocks on the magnitudes of the CEO cycles in Appendix C. These tests, described in detail in Appendix C, suggest that the existence and the magnitudes of the CEO investment cycles are not sensitive to the industry conditions at the time when new CEOs take office. Therefore, the CEO investment cycle does not appear to occur because of productivity shocks coinciding with the CEO changes.

\subsection{CEO Power and Investment}

\subsubsection{The CEO's Capture of the Board and Investment}

To test Implication 4, that the increase in investment over CEO tenure is a function of the CEO's growing power over his board, we construct a variable that is likely to be highly correlated with the CEO's power over the board as well as his tenure, and evaluate the extent to which this variable explains the relation between CEO tenure and corporate investment. Specifically, we calculate the fraction of directors that are appointed after the CEO takes office ("\% of New Directors"). The idea, formalized in Hermalin and Weisbach (1998), is that the CEO will use his influence to ensure that the firm appoints directors who are unlikely to oppose any actions he wishes to take.

We construct this variable using data from RiskMetrics, which provides the starting and ending years for each director in the S\&P 1500 firms during 1996 to 2011. For each firm-year in our sample, we count the number of directors who start their directorship after the current CEO takes office, and scale it by the total number of directors on the board in that year. ${ }^{14}$ By construction, $\%$ of New Directors is highly correlated with the CEO's time in office: The correlation between the two is 0.68 , which is much higher than the correlations between CEO tenure and other proxies for CEO power (e.g., the correlation between CEO tenure and CEO ownership is 0.22, and between CEO tenure and CEO being Chairman is 0.20 ).

\footnotetext{
${ }^{14}$ Both Morse et al. (2011) and Coles et al. (2013) document that this measure of CEO power is associated with less effective board monitoring: higher level of managerial pay, but lower level of incentives provided to managers, and lower level of turnover-performance sensitivity. In addition, similar to the results reported below, Coles et al. independently find that a firm's investments are increasing with the level of the board's cooption.
} 
Panel A of Table 8 presents estimates of the relation between CEO tenure and \% of New Directors in a multivariate setting. The estimates in Column (1) imply that the CEO's time in office (together with firm fixed effects) alone explains $78 \%$ of the variation in $\%$ of New Directors. Column (2) controls for other measures of CEO power and firm performance that potentially explain director turnover; however, the relation between CEO tenure and \% of New Directors is largely unchanged. The magnitude of the coefficient on CEO tenure implies that as the CEO's time in office increases by one year, the fraction of new directors on the board on average increases by about five percentage points. Given that the average board size is 9 , this estimate implies that approximately one new director is added every other year during the CEO's tenure, which is similar to director turnover rates reported elsewhere (see, for example, Hermalin and Weisbach (1988)).

In Panel B of Table 8, we test Implication 4 by including \% of New Directors in specifications similar to those reported in Table 5. Tenure and \% of New Directors are highly correlated with one another, but \% of New Directors directly reflects the CEO's control over the board. Therefore, if the effect of tenure on investment occurs because of the fact that tenure is correlated with the CEO's power inside the firm, then the tenure effect should be picked up by \% of New Directors. Alternatively, if there is some other reason why tenure is related to investment, then estimates of the effect of tenure on investment should be relatively unaffected by including \% of New Directors into the equation.

In the estimated equations reported in Columns (1)-(4) of Panel B of Table 8, \% of New Directors is positively related to both components of investment, capital expenditures and acquisitions, and also positively related to the asset growth rate. The effect of \% of New Directors on acquisition intensity (0.27) is much stronger than on capital expenditures (0.07). Large and non-recurring investments such as acquisitions are more subject to the board scrutiny than routine capital expenditures, so the larger coefficient on acquisitions than on capital expenditures suggests that our measure indeed reflects the CEO's capture of the board. Potentially more important, once we control for \% of New Directors, the variable that indicates if the CEO is in the first two years of his tenure no longer has any effect on 
investment intensity. ${ }^{15}$ The fact that the effect of tenure on investment disappears when we control for $\%$ of New Directors suggests that the channel through which CEO tenure affects investment is through the control over the board that the CEO acquires over time.

In contrast, Columns (5) and (6) show that controlling for \% of New Directors does not mitigate the effect of CEO tenure on employment growth rate or on disinvestment intensity. The result on employment growth is puzzling, since the CEO's preference for growing the firm could be reflected in the size of both physical capital and labor. One potential explanation is that corporate hiring could be subject to less board scrutiny than corporate investment. The fact that the increasing CEO capture of the board over time does not explain the CEO disinvestment cycle is consistent with our hypothesis that the disinvestment cycle is explained by CEO turnover facilitating error correction and re-optimization than the CEO's preference for firm size and growth. ${ }^{16}$

\subsubsection{Instrumental Variable Estimates}

One potential concern is that director turnover is endogenous and could depend on the firm's performance, investment strategies, and growth opportunities. To address this concern, we follow Fracassi and Tate (2012) and use the retirement of directors to identify the demand for new directors that is not a function of the firm's conditions. ${ }^{17}$ Most companies have a mandatory retirement age of 72 for outside directors (see, e.g., Larcker 2011), and inside directors' mandatory retirement age is usually around 65. Using these conventions, we construct a measure of the "exogenous" retirements of directors counting a director departure as retirement related if the departing director is an outside director and is at least 72 years old or is an inside director and is at least 65 . Our instrument for \% of New Directors is the

\footnotetext{
${ }^{15} \mathrm{We}$ obtain similar results if we replace Years [0,2] with the continuous CEO tenure variable.

${ }^{16}$ We also re-estimate the equations in Panel B of Table 8 replacing \% of New Directors with CEO ownership or a dummy variable indicating that $\mathrm{CEO}$ is also the chairman (results not reported). Including these two variables that are likely correlated with CEO power does not change the effect of CEO tenure on investment and disinvestment. We also include all three measures of CEO power in one equation, and obtain results similar to those reported in Panel B of Table 8. These findings suggest that measures of growing CEO power over time can better explain the CEO investment cycles than other more static/dichotomous measures of CEO power.

${ }^{17}$ Fracassi and Tate (2012) provide a battery of validity tests for this identification strategy. In particular, they find that director retirement does not appear to be correlated with firm performance and investment opportunities. Larcker (2011) also show that directors tend to retire voluntarily, and only $2 \%$ of director departures are due to dismissals or failure to be re-elected.
} 
cumulative number of retired directors since the current CEO takes office scaled by the board size ("Retired Directors"). The average value of the instrument is $12.4 \%$.

Panel $\mathrm{C}$ of Table 8 reports the instrumental variable estimation results. The first stage results as well as the F-statistics indicate that our instrument is positively and significantly related to the endogenous variable \% of New Directors. The second stage results suggest that the exogenous variation in \% of New Directors due to director retirements still leads to more corporate investment and higher firm growth rate (including employment growth rate). This result suggests that there is a causal impact of the growing CEO capture of the board over time on investment and growth.

\subsubsection{Investment Quality over CEO Tenure}

An additional implication of the CEO power interpretation of the CEO investment cycle is that the quality of the firm's investments decreases over the CEO cycle. Ass discussed above, this implication is not consistent with potential alternative explanations of the increase in investment over the CEO cycle.

We measure the quality of the firm's investments using the stock market reaction to announcements to the firm's acquisitions. Column (1) of Panel D of Table 8, presents estimates of equations that indicate that the three-day market-adjusted return to acquisition announcements is on average 20 basis points higher if the acquisition is announced in the first three years of a CEO's tenure than in later years, after controlling for deal and firm characteristics. Moreover, $39 \%$ of the deals made in the first 3 years have negative announcement returns, while $58 \%$ of the deals in later years have negative announcement returns.

Column (2) shows that the market reaction is negatively associated with \% of New Directors, suggesting that the CEO's growing influence over the board is associated with deteriorating acquisition quality. Columns (3) and (4) show that these results hold even when the departures are not forced. Column (5) uses Retired Directors as an instrument for the percent of new directors, and suggests the CEO's capture of the board causally affects acquisition quality.

Overall, the results in Section 5.4 are consistent with the view that as a CEO's power grows in a firm, he will tend to increase his investment, and that the incremental investments will tend to be of lower 
quality. This increase appears to be more related to a direct measure of the CEO's control, the fraction of directors he personally was responsible for appointing, than simply his time in office. The deteriorating investment quality over CEO tenure is not consistent with the non-agency based views in which a CEO's time in office reflects the firm's investment opportunity, the CEO's experience, or a potential financing constraint caused by the change of leadership.

We also emphasize that not all agency theories are consistent with our results. For example, the "quiet life" arguments of Bertrand and Mullanaithan (2003) suggest the opposite: their hypothesis implies that as managers acquire power, they do whatever they can to make their job easier. Our results are inconsistent with this view; instead, they imply that as CEO's power grows in a firm, he will use it to overcome whatever constraints the board imposes on them and invest in the projects they prefer.

\section{Summary and Implications}

One of the most important things we study in business schools is the role of management in public companies. Much of what we teach presumes that management decisions make a difference, and that firms in reality are not in the "first-best" world described by many economic models. Yet, identifying the importance of management empirically is problematic for a number of reasons. CEOs are endogenously matched to firms, so it is impossible to attribute any performance to a particular CEO. Moreover, most managerial actions are unobservable, and even if they are observable, it is difficult to attribute any value consequences to them.

Our paper addresses this issue by documenting a systematic relation between CEO tenure and the firm's investment, which we refer to as the CEO Investment Cycle. Shortly after a new CEO takes office, the firm's rate of disinvestment rises sharply and investment is relatively low. As the CEO's tenure lengthens, the disinvestment rate declines while the investment rate, especially of acquisitions, increases substantially. This CEO investment cycle occurs regardless of whether the CEO change occurs because of a firing or for exogenous reasons, and regardless of the background of the incoming CEO. The CEO cycle 
effect on investment is of the same order of magnitude as the effects of other well-known factors such as the business cycle, political uncertainty, and financial constraints.

We argue that the most plausible explanation for the CEO investment cycle is a combination of two agency-based effects: First, CEOs are reluctant to divest or re-optimize on bad investments that they have made due to private benefits or career concerns. It often takes a new CEO to enforce optimal disinvestment, leading to high disinvestment intensity shortly after CEO turnover. Second, CEOs have many reasons to prefer more investment than is optimal from a value-maximization perspective. As the CEO acquires more influence over the board, his ability to overinvest increases, leading to increasing investment with CEO tenure.

We provide a series of tests that support this interpretation of investment behavior we observe over the CEO cycle. Consistent with the agency explanation for disinvestment, the divested units tend to be poor performers established by the previous management. However, the tendency of CEOs to disinvest quickly poorly performing units acquired by their predecessors is lower when the incoming CEO had a role in the prior management, or if the prior management maintains a strong presence on the board of directors after turnover. On the investment side, we find that direct measures of the CEO's control over the board appear to be more important than the CEO's tenure in office for explaining the investment increases. Moreover, as the investment quantity increases with tenure, the investment quality decreases. These findings suggest that the increases in investment over the CEO cycle occur because the CEO acquires control over his board over time, and the investment increases are not efficient.

In contrast, arguments based on differing CEO skills, exogenous productivity shocks, or CEO tenure endogenously reflecting the firm's investment opportunities do not explain the nature and magnitude of the CEO investment cycles.

These findings about the CEO investment cycle have a number of important implications. First, they document that factors internal to the firm affect investment in a meaningful way. Much attention in the economics literature has been paid to the effect of economy-wide variables such as tax policies, business cycles, and financial constraints on firms' investments. For example, the Q theory of investment 
and asset prices focuses entirely on exogenous and external determinants of investment. Yet, the governance-related effects that we document in this paper are of the same order of magnitude as these often-studied external factors. While much attention has been given in the academic literature to corporate governance lately, its impact on the quantity of investment likely has been understated, and should be incorporated into models of investment.

Second, the existence and magnitude of the CEO investment cycle highlights the limitations of public corporations as a vehicle of ensuring optimal investment. A related puzzle concerns the way in which private equity firms are able to pay large (30\%) premiums for target companies, very large fees, and still create enough value in those companies to earn positive returns for their investors. When asked, private equity general partners often emphasize the improvements in governance that they are able to enact in target companies; the existence of such large and systematic pattern in investment over the CEO cycle in public corporations suggests that this argument is credible. In addition, recent studies show that CEO turnovers are less frequent in private companies than in public companies (Cornelli and Karakas 2013, Gao, Harford, and Li 2013). An implication of our results is that in public companies, such regular turnover is potentially important, because it is part of the process of controlling agency problems.

Third, it seems likely that whatever inefficiencies implied by the existence of the CEO investment cycle understate the inefficiencies due to agency problems. We document that there are substantial differences in investment quantity over the CEO cycle, implying that firms' investment deviate from the first-best level in important ways. Yet, our analysis focuses mainly on the quantity and quality of investment, ignoring other factors as its risk, horizon, etc. There are a number of theories that characterize the manner in which principal-agent problems can lead to distortions away from the first-best investments along these dimensions. Quantifying the nature of these distortions is likely to be a fruitful direction for future research. 


\section{References}

Ball, Christopher, Gerard Hoberg, and Vojislav Maksimovic, 2013, "Redefining Financial Constraints: A Text-Based Analysis," Working Paper.

Baumol, William J., 1959, "Business Behavior, Value and Growth,” The Macmillan Company, London.

Bebchuk, Lucian and Jesse Fried, 2004, "Pay without Performance: The Unfilled Promise of Executive Compensation,” Harvard University Press, Cambridge, MA.

Bennedsen, Morten, Francisco Pérez-González, Kasper Nielsen, and Daniel Wolfenzon, 2007, "Inside the Family Firm: The Role of Families in Succession Decisions and Performance," Quarterly Journal of Economics, 122 (2), 647-691.

Bennedsen, Morten, Francisco Pérez-González, and Daniel Wolfenzon, 2012, "Estimating the Value of the Boss: Evidence from CEO Hospitalization Events," Working Paper.

Berle, Adolf and Gardiner Means, 1932, "The Modern Corporation and Private Property," Macmillan, New York.

Bertrand, Marianne and Sendhil Mullainathan, 2003, "Enjoying the Quiet Life? Corporate Governance and Managerial Preferences," Journal of Political Economy, 111(5), 1043-1075.

Bertrand, Marianne and Antoinette Schoar, 2003, "Managing with Style: The Effect of Managers on Firm Policies," Quarterly Journal of Economics, 118(4), 1169-1208.

Boot, Arnoud W.A., 1992, "Why Hang on to Losers? Divestitures and Takeovers," Journal of Finance, 47, 1401-1423.

Coles, Jeffrey, Naveen Daniel and Lalitha Naveen, 2013, "Co-opted Boards: Costs, Benefits, Causes and Consequences," Working Paper.

Cornelli, Francesca, and Oğuzhan Karakas, 2013, "CEO Turnover in LBOs: The Role of Boards," Working Paper.

Cremers, Martijn and Yaniv Grinstein, 2011, "The Market for CEO Talent: Implications for CEO Compensation," Working Paper.

Cunha, Igor and Rafael P. Ribas, 2012, "Back in Style (Limited Edition): Contrasts in Style and CEO Impact on Corporate Policy," Working Paper.

Demsetz, Harold and Kenneth Lehn, 1985, “The Structure of Corporate Ownership," Journal of Political Economy, 93: 1155-77.

Desai, Mihir A. and Austan D. Goolsbee, "Investment, Overhang, and Tax Policy," Brookings Papers on Economic Activity, 2004 (2), 285-338.

Donaldson, Gordon, 1984, "Managing Corporate Wealth," Praeger Publishers, New York. 
Eisfeldt, Andrea and Camilia M. Kuhnen, 2012, "CEO Turnover in a Competitive Assignment Framework," Journal of Financial Economics, forthcoming.

Fee, C. Edward, Charles J. Hadlock, and Joshua R. Pierce, 2013, "Managers Who Lack Style: Evidence from Exogenous CEO Changes," Review of Financial Studies, forthcoming.

Fracassi, Cesare and Geoffrey Tate, 2012, "External Networking and Internal Firm Governance," The Journal of Finance, 67(1), 153-194.

Gao, Huasheng, Jarrad Harford, and Kai Li, 2013, "Investor myopia and CEO turnover: Evidence from private firms," Working Paper.

Hermalin, Benjamin E. and Michael S. Weisbach, 1988, "The Determinants of Board Composition," Rand Journal of Economics, 19, 589-606.

Hermalin, Benjamin E. and Michael S. Weisbach, 1998, "Endogenously Chosen Boards of Directors and their Monitoring of the CEO," American Economic Review, 88, 96-118.

Jensen, Michael C., 1986, "The Agency Costs of Free Cash Flow: Corporate Finance and Takeovers," American Economic Review, 76(2), 323-29.

Jensen, Michael C. and Meckling, William H., 1976, "Theory of the Firm: Managerial Behavior, Agency Costs and Ownership Structure,” Journal of Financial Economics, 3(4), 305-360.

Jensen, Michael C and Murphy, Kevin J, 1990, "Performance Pay and Top-Management Incentives," Journal of Political Economy, 98 (2), 225-64.

Johnson, Bruce W., Robert Magee, Nandu Nagarajan, and Herry Newman, 1985, "An Analysis of the Stock Price Reaction to Sudden Executive Death: Implications for the Management Labor Market," Journal of Accounting and Economics, 7, 151-174.

Jorgenson, Dale and and Z Griliches, 1967, "The Explanation of Productivity Change". The Review of Economic Studies 34(3): 249-280.

Julio, Brandon and Youngsuk Yook, 2012, "Political Uncertainty and Corporate Investment Cycle," Journal of Finance, 67(1), 45-84.

Kanodia, Chandra, Robert Bushman, and John Dickhaut, 1989, "Escalation Errors and the Sunk Cost Effect: An Explanation Based on Reputation and Information Asymmetries," Journal of Accounting Research, 27(1), 59-77.

Larcker, David, 2011, "Board of Directors: Selection, Compensation, and Removal,” Working Paper.

Li, Xiaoyang, Angie Low, and Anil K. Makhija, 2011, "Career Concerns and the Busy Life of Young CEOs", Working Paper.

Maksimovic, Vojislav and Gordon Phillips, 2002, "Do Conglomerate Firms Allocate Resources Inefficiently Across Industries? Theory and Evidence,” The Journal of Finance, 67, 721-767.

Marris, R., 1964, “The Economic Theory of Managerial Capitalism,” Free Press of Glencoe, Glencoe, IL. 
Morck, R., A. Shleifer and R. Vishny, 1990, "Do Managerial Objectives Drive Bad Acquisitions?” The Journal of Finance, 45(1), 31-48.

Morse, Adair, Vikram Nanda and Amit Seru, 2011, "Are Incentive Contracts Rigged by Powerful CEOs?" The Journal of Finance, 1779-1821

Murphy, Kevin J. and Ján Zábojník, 2007, "Managerial Capital and the Market for CEOs," Working Paper.

Myers, Stewart C., 1977, "Determinants of Corporate Borrowing," Journal of Financial Economics, 5, $147-175$.

Murphy, Kevin J. and Jerold L. Zimmerman, 1993. "Financial performance surrounding CEO turnover," Journal of Accounting and Economics, 16, 273-315.

Pan, Yihui, Tracy Yue Wang, and Michael S. Weisbach, 2013, "Learning about CEO Ability and Stock Return Volatility," Working Paper.

Parrino, Robert, 1997, "CEO Turnover and Outside Succession: A Cross-sectional Analysis," Journal of Financial Economics, 46, 165-197.

Roll, Richard, 1986, "The Hubris Hypothesis of Corporate Takeovers," Journal of Business, 59 (2), 197216.

Sheifer, Andrei and Robert W. Vishny, 1989, "Management Entrenchment: The Case of Manager-specific Investments," Journal of Financial Economics, 25(1), 123-139.

Summers, Lawrence H., Barry P. Bosworth, James Tobin, and Philip M. White, 1981, "Taxation and Corporate Investment: A q-Theory Approach," Brookings Papers on Economic Activity, 1981 (1), 67-140.

Tirole, Jean, 2006, “The Theory of Corporate Finance,” Princeton University Press, Princeton, 2006.

Weisbach, Michael S., 1995, "CEO Turnover and the Firm's Investment Decisions," Journal of Financial Economics, 37, 155-188.

Williamson, Oliver E., 1964, "The Economics of Discretionary Behavior: Managerial Objectives in a Theory of the Firm," Prentice-Hall, Englewood Cliff.

Yermack, David and Anil Shivdasani, 1999, "CEO Involvement in the Selection of New Board Members: An Empirical Analysis,” Journal of Finance, 54, 1829-1853.

Yim, Soojin, 2013, "The Acquisition of Youth: CEO Age and Acquisition Behavior", Journal of Financial Economics, Forthcoming. 


\section{Table 1: Summary Statistics}

\section{Panel A: Turnover Year Distribution}

This table reports the distribution of CEO turnovers by year. We use the information on job title, the year becoming CEO, and the CEO annual flag provided in ExecuComp to identify CEOs at the firm-year level. For each firm, we compare the designated CEO in each fiscal year with the CEO in the previous year to identify whether there is a CEO turnover in that year. Turnover year is identified as the year of "becameceo" for each new CEO in ExecuComp which covers reining CEOs for S\&P 1,500 firms from 1992 to 2009. Although ExecComp's coverage starts in 1992, some of the CEOs in the database took office before 1992, leading to some CEO turnovers from the 1980s being in our sample.

\begin{tabular}{lcc}
\hline Became CEO Year & Freq. & Percent \\
\hline $1980-1989$ & 867 & 16.00 \\
$1990-1994$ & 978 & 18.04 \\
$1995-1999$ & 1,284 & 23.69 \\
$2000-2004$ & 1,226 & 22.62 \\
$2005-2009$ & 1,065 & 19.65 \\
\hline Total & 5,420 & 100 \\
\hline
\end{tabular}

\section{Panel B: CEO Attributes and Turnover Types}

This table reports the summary statistics for CEO attributes and turnover types at the firm-CEO level. CEO age and the succession origin are classified as of the turnover year. "Outside Succession" is an indicator variable that equals 1 if the new CEO is appointed from outside of the firm. "Exogenous Turnover" is an indicator variable that equals 1 if the turnover is due to deaths, illness, and retirements of the departing CEOs. "Forced Turnover" is an indicator variable that equals 1 if the turnover is related to outright firing of the CEOs, and is constructed based on the data for Fee et al. (2013) which covers turnovers at US Compustat firms from 1990 to 2007, except for financial firms, regulated utilities and firms with below \$10 million in 1990 inflation-adjusted assets, therefore with more missing values. \% On Board [old mgt.] is the percentage of old management (top-4 highest paid executives except for the CEO) from the previous regime that still serves as directors on the board during the first year of the new CEO's tenure. Stay As Chairman [old CEO] is an indicator variable equals if the old CEO stays as the Chairman of the Board during the first year of the new CEO's tenure. The director data is from RiskMetrics which starts from 1996.

\begin{tabular}{lccccc}
\hline CEO Attribute & Obs & Mean & $25^{\text {th }}$ percentile & Median & $75^{\text {th }}$ percentile \\
\hline CEO Age (at turnover) & 5,172 & 51.280 & 46 & 51 & 56 \\
CEO Total Time in Office & 5,420 & 6.989 & 3 & 6 & 10 \\
\hline
\end{tabular}

\begin{tabular}{lcc}
\hline Turnover-Related Variable & Obs & Mean \\
\hline Outsider Succession & 5,223 & 0.335 \\
Exogenous Turnover & 5,223 & 0.096 \\
Forced Turnover & 4,382 & 0.073 \\
\hline \% On Board [old mgt.] & 2,560 & 0.250 \\
Stay As Chairman [old CEO] & 3,402 & 0.277 \\
\hline
\end{tabular}




\section{Panel C: Disinvestment and Investment Variables}

This table reports summary statistics of the main disinvestment and investment variables in this study. "Discontinued operations" is the absolute value of the income from discontinued operations (item "DO" in Compustat). "Disinvestment Rate" equals (value of asset sales + value of discontinued operations]/lagged net PPE. "Acquisition Rate" is the value of acquired assets divided by lagged net PPE. "Capx Rate" is capital expenditures divided by lagged net PPE. "Investment Rate" is the sum of acquisition and capital expenditures scaled by lagged net PPE. "Asset Growth Rate" is the annual growth rate of book assets, and "Employment Growth Rate" is the annual growth rate of the firm's number of employees. The two indicator variables related to announcements are constructed at the firm-month level, the two indicator variables related to segment start and termination are constructed at the firm-segment-year level, while other variable at the firm-year level. Downsizing and expansion announcements are from the Capital IQ database with coverage starting after 2000. Segment variables are constructed using Compustat (historical) segment database. Our sample includes S\&P 1,500 firms with available data on total assets and identifiable CEOs from Execucomp, over the period 1980-2011.

\begin{tabular}{|c|c|c|c|c|c|}
\hline Disinvestment & Obs & Mean & $25^{\text {th }}$ percentile & Median & $75^{\text {th }}$ percentile \\
\hline$I_{\{\text {asset sales }>0\}}$ & 39,292 & 0.089 & 0 & 0 & 0 \\
\hline$I_{\{\text {discontinued operations }>0\}}$ & 39,292 & 0.157 & 0 & 0 & 0 \\
\hline$I_{\{\text {asset sales }>0 \text { or discontinued operations }>0\}}$ & 39,292 & 0.210 & 0 & 0 & 0 \\
\hline$I_{\{\text {If there is downsizing announcement(s) in the month }\}}$ & 245,677 & 0.040 & 0 & 0 & 0 \\
\hline$I_{\{\text {segment termination\} }}$ & 196,717 & 0.095 & 0 & 0 & 0 \\
\hline Disinvestment Rate & 36,901 & 0.041 & 0 & 0 & 0 \\
\hline $\begin{array}{l}\text { Disinvestment Rate } \\
\text { (conditional on disinvestment occurring) }\end{array}$ & 6,454 & 0.232 & 0.011 & 0.050 & 0.202 \\
\hline Restructuring Rate & 36,901 & 0.023 & 0 & 0 & 0 \\
\hline $\begin{array}{l}\text { Restructuring Rate } \\
\text { (conditional on restructuring occurring) }\end{array}$ & 6,617 & 0.085 & 0.014 & 0.043 & 0.114 \\
\hline \multicolumn{6}{|l|}{ Investment } \\
\hline$I_{\{\text {If there is expansion announcement(s) in the month\} }}$ & 245,677 & 0.081 & 0 & 0 & 0 \\
\hline$I_{\{\text {segment start\} }}$ & 216,569 & 0.161 & 0 & 0 & 0 \\
\hline Acquisition Rate & 36,901 & 0.338 & 0 & 0 & 0 \\
\hline Capx Rate & 36,901 & 0.327 & 0.113 & 0.203 & 0.363 \\
\hline Investment Rate & 36,901 & 0.666 & 0.126 & 0.239 & 0.497 \\
\hline \multicolumn{6}{|l|}{ Net Effects } \\
\hline Asset Growth Rate & 38,460 & 0.203 & -0.004 & 0.076 & 0.208 \\
\hline Employment Growth Rate & 36,575 & 0.094 & -0.033 & 0.030 & 0.134 \\
\hline
\end{tabular}




\section{Panel D: Other Firm Level Control Variables}

This table reports summary statistics for firm-year level financial attributes, governance related variables, and dealspecific variables (in acquisitions). All variable definitions are provided in Appendix A. Firm attributes are constructed using data from Compustat. Governance variables are constructed using data from RiskMetrics and Execucomp. Deal-specific variables are constructed using data from SDC Platinum. Mkt-adj. announcement day returns are constructed using CRSP data.

\begin{tabular}{|c|c|c|c|c|c|}
\hline Firm Attribute & Obs & Mean & $\begin{array}{c}25^{\text {th }} \\
\text { percentile }\end{array}$ & Median & $\begin{array}{c}75^{\text {th }} \\
\text { percentile }\end{array}$ \\
\hline Firm Age & 39,193 & 18.626 & 7 & 16 & 30 \\
\hline Ind-adj.ROA & 37,223 & 0.057 & -0.008 & 0.033 & 0.114 \\
\hline Ind-adj. Return & 36,580 & 0.147 & -0.158 & 0.039 & 0.280 \\
\hline MB & 37,680 & 2.877 & 1.327 & 2.042 & 3.333 \\
\hline Leverage & 39,069 & 0.241 & 0.065 & 0.213 & 0.355 \\
\hline Div. Payer & 39,292 & 0.522 & 0 & 1 & 1 \\
\hline Log(Assets) & 39,291 & 7.108 & 5.814 & 7.085 & 8.425 \\
\hline Cash Ratio & 43,391 & 0.093 & 0.015 & 0.046 & 0.122 \\
\hline$\%$ of New Directors & 16,220 & 0.520 & 0.250 & 0.500 & 0.778 \\
\hline Retired directors & 16,220 & 0.124 & 0 & 0 & 0.167 \\
\hline CEO PPS & 22,334 & 0.022 & 0.002 & 0.006 & 0.017 \\
\hline $\begin{array}{l}\text { CEO Ownership } \\
\text { CEO is also the Chairman of the }\end{array}$ & 28,873 & 0.018 & 0.001 & 0.003 & 0.010 \\
\hline Board & 14,653 & 0.617 & 0 & 1 & 1 \\
\hline Deal Attribute & Obs & Mean & $\begin{array}{c}25^{\text {th }} \\
\text { percentile }\end{array}$ & Median & $\begin{array}{c}75^{\text {th }} \\
\text { percentile }\end{array}$ \\
\hline $\begin{array}{l}\text { CAR }[-1,1] \text { around Acquisition } \\
\text { Announcements }\end{array}$ & 15,749 & 0.002 & -0.011 & 0 & 0.014 \\
\hline Public Target & 15,749 & 0.230 & 0 & 0 & 0 \\
\hline $\log ($ Deal Value $)$ & 14,761 & 3.753 & 2.681 & 3.848 & 5.011 \\
\hline$\%$ of Stock & 15,678 & 0.185 & 0 & 0 & 0.155 \\
\hline
\end{tabular}




\section{Table 2: Disinvestment Probability and CEO Tenure}

\section{Panel A: Disinvestment Trend over CEO Tenure}

This table reports the trend in disinvestment probability over CEO tenure starting from the year the CEO took office (Tenure $=0$ for the became-CEO year based on Execucomp), for the full sample as well as the exogenous turnover sample. The disinvestment probability is the average value of the various indicator variables capturing whether the firm has asset sales and/or discontinued operations in the fiscal year. The definitions of all turnover types are in Appendix A.

\begin{tabular}{|c|c|c|c|c|c|c|}
\hline \multirow[b]{2}{*}{ Tenure } & \multicolumn{2}{|c|}{$I_{\{\text {asset sales }>0 \text { or discontinued operations }>0\}}$} & \multicolumn{2}{|c|}{$I_{\{\text {asset sales }>0\}}$} & \multicolumn{2}{|c|}{$I_{\{\text {discontinued operations }>0\}}$} \\
\hline & Full Sample & Exogenous Turnover & Full Sample & Exogenous Turnover & Full Sample & Exogenous Turnover \\
\hline 0 & 0.192 & 0.264 & 0.082 & 0.124 & 0.164 & 0.196 \\
\hline 1 & 0.212 & 0.271 & 0.092 & 0.116 & 0.179 & 0.219 \\
\hline 2 & 0.201 & 0.251 & 0.087 & 0.118 & 0.171 & 0.209 \\
\hline 3 & 0.190 & 0.241 & 0.081 & 0.122 & 0.166 & 0.207 \\
\hline 4 & 0.180 & 0.199 & 0.077 & 0.069 & 0.161 & 0.197 \\
\hline 5 & 0.163 & 0.147 & 0.067 & 0.058 & 0.158 & 0.143 \\
\hline 6 & 0.155 & 0.155 & 0.065 & 0.071 & 0.146 & 0.154 \\
\hline 7 & 0.154 & 0.124 & 0.067 & 0.073 & 0.146 & 0.109 \\
\hline 8 & 0.137 & 0.132 & 0.054 & 0.075 & 0.146 & 0.126 \\
\hline
\end{tabular}


Panel B: Disinvestment Probability and CEO Tenure

The dependent variables are the disinvestment indicator variable $I_{\{\text {asset sales }>0 \text { or discontinued operations }>0\}}$. Observations are at the firm-year level. Models (1) to (8) present results for the full sample as well as various subsamples for long-term CEOs (more than 6 years total time in office) and different turnover types. A constant term is included in all models but omitted for brevity. Other control variables except for Firm Age are lagged. Firm and Year Fixed effects are included in all models. The definitions of all variables are in Appendix A. The Huber-White-Sandwich robust standard errors are clustered by firm and reported in parenthesis. $* * *, * *$ and $*$ indicate significance at the $1 \%, 5 \%$ and $10 \%$ levels respectively.

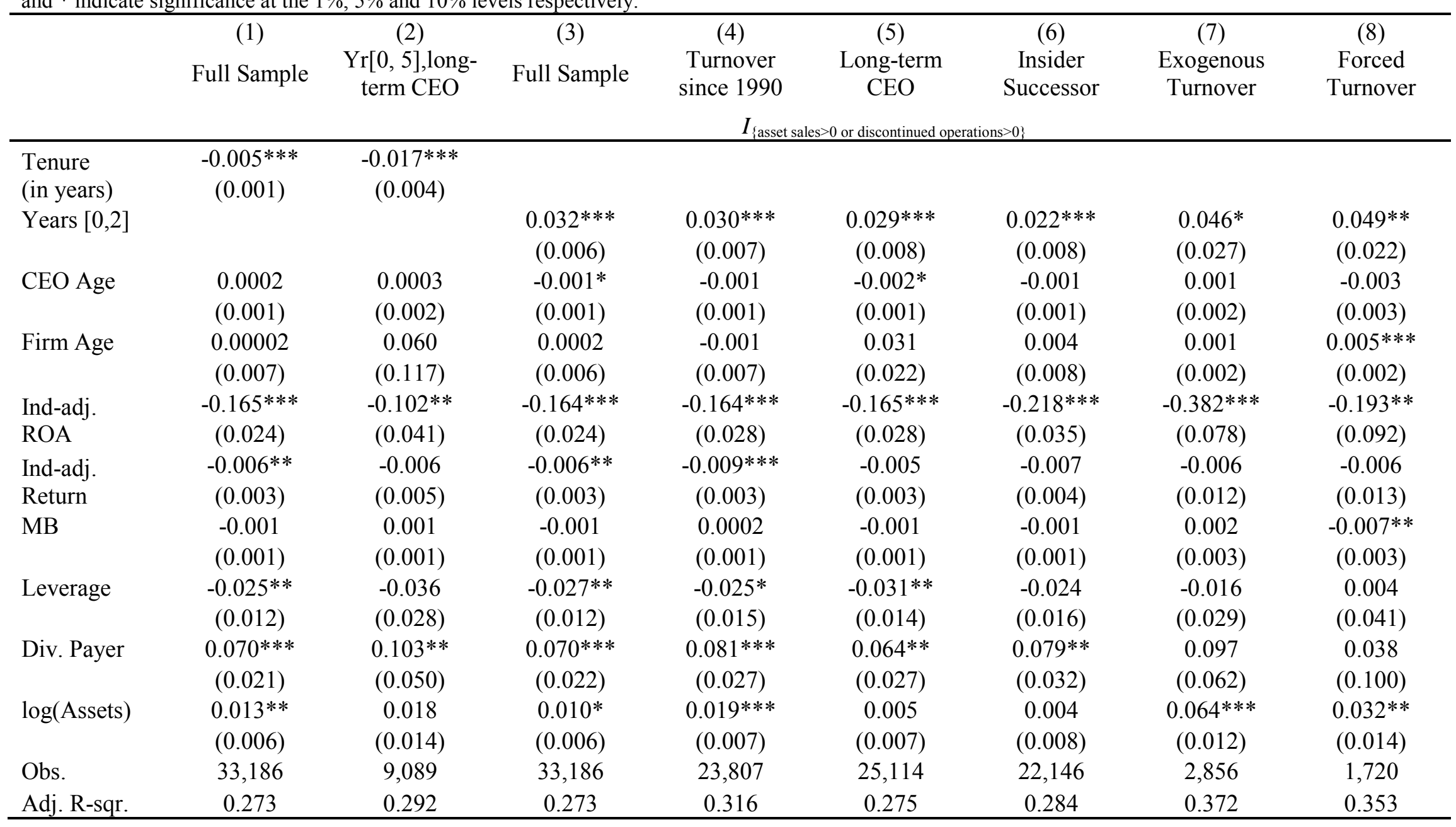




\section{Panel C: Downsizing Announcements and Segment Termination}

In Columns (1) and (2), the dependent variables are the downsizing announcement indicator $I_{\text {\{downsizing announcement(s) in }}$ the month\}. Observations are at the firm-month level. Downsizing announcements are from the Capital IQ database with coverage starting after 2000. "Months [0,24]" is an indicator variable that equals 1 for the first 24 months of a CEO's tenure, and 0 for later months. In Columns (3) and (4), the dependent variables are the segment termination indicator $I_{\text {\{segment termination\} }}$. Observations are at the segment-year level. The data is from Compustat "historical segment" database, and we only inclue multi-segment firm-years. "Years [0, 2]" is an indicator variable that equals 1 for the first 3 years of a CEO's tenure, and 0 for later years. "Underperforming Segment" is an indicator variable that equals 1 if the lagged segment operating profits/losses over sales is at the bottom $10 \%$ of the sample distribution (less than -7.4\%). Segment Age is the number of years since the establishment of the segment. The definitions of all variables are in Appendix A. Regressions include but do not report the constant term. The Huber-White-Sandwich robust standard errors are clustered by firm and reported in parenthesis. $* * *, * *$ and $*$ indicate significance at the $1 \%$, $5 \%$ and $10 \%$ levels respectively.

\begin{tabular}{|c|c|c|c|c|}
\hline & \multicolumn{2}{|c|}{$I_{\{\text {downsizing announcement(s) in the month\} }}$} & \multicolumn{2}{|c|}{$I_{\{\text {segment termination\} }}$} \\
\hline & (1) & (2) & (3) & (4) \\
\hline & & Exogenous & & Exogenous \\
\hline & Full Sample & Turnover & Full Sample & Turnover \\
\hline \multirow[t]{2}{*}{ Months $[0,24]$} & $0.011 * * *$ & $0.007^{*}$ & & \\
\hline & $(0.002)$ & $(0.004)$ & & \\
\hline \multirow[t]{2}{*}{ Years $[0,2]$} & & & $0.005 * * *$ & $0.012 * *$ \\
\hline & & & $(0.002)$ & $(0.006)$ \\
\hline \multirow[t]{2}{*}{ CEO Age } & 0.0001 & 0.00003 & 0.0001 & -0.0002 \\
\hline & $(0.0001)$ & $(0.0002)$ & $(0.0002)$ & $(0.001)$ \\
\hline \multirow[t]{2}{*}{ Firm Age } & -0.00001 & 0.0001 & $0.094 * * *$ & 0.014 \\
\hline & $(0.0001)$ & $(0.0002)$ & $(0.025)$ & $(0.011)$ \\
\hline \multirow[t]{2}{*}{ Ind-adj. ROA } & $-0.014 * * *$ & -0.002 & 0.015 & -0.008 \\
\hline & $(0.005)$ & $(0.011)$ & $(0.013)$ & $(0.039)$ \\
\hline \multirow[t]{2}{*}{ Ind-adj. Return } & $-0.004 * * *$ & $-0.005 * *$ & -0.0002 & $-0.008 * * *$ \\
\hline & $(0.001)$ & $(0.002)$ & $(0.001)$ & $(0.003)$ \\
\hline \multirow[t]{2}{*}{ MB } & $-0.001 * * *$ & -0.001 & -0.0002 & 0.0004 \\
\hline & $(0.000)$ & $(0.001)$ & $(0.0002)$ & $(0.001)$ \\
\hline \multirow[t]{2}{*}{ Leverage } & 0.006 & -0.004 & $0.006^{*}$ & $0.014^{*}$ \\
\hline & $(0.005)$ & $(0.017)$ & $(0.003)$ & $(0.008)$ \\
\hline \multirow[t]{2}{*}{ Div. Payer } & $0.016^{* * *}$ & $0.016 * *$ & $-0.018 * *$ & 0.016 \\
\hline & $(0.003)$ & $(0.007)$ & $(0.008)$ & $(0.033)$ \\
\hline \multirow[t]{2}{*}{$\log$ (Assets) } & $0.019 * * *$ & $0.014 * *$ & $0.011 * * *$ & 0.008 \\
\hline & $(0.002)$ & $(0.006)$ & $(0.002)$ & $(0.008)$ \\
\hline \multirow[t]{2}{*}{ Underperforming Segment } & & & $0.109 * * *$ & $0.088 * * *$ \\
\hline & & & $(0.005)$ & $(0.013)$ \\
\hline \multirow[t]{2}{*}{ \# of Segments } & & & $-0.002 * *$ & 0.005 \\
\hline & & & $(0.001)$ & $(0.003)$ \\
\hline \multirow[t]{2}{*}{ Segment Age } & & & $-0.002 * * *$ & $-0.002 * * *$ \\
\hline & & & $(0.0001)$ & $(0.0003)$ \\
\hline Firm and Year F.E. & $\mathrm{x}$ & $\mathrm{x}$ & $\mathrm{x}$ & $\mathrm{x}$ \\
\hline Obs. & 209,736 & 42,072 & 120,379 & 13,688 \\
\hline Adj. R-sqr. & 0.134 & 0.144 & 0.076 & 0.094 \\
\hline
\end{tabular}




\section{Panel D: Disinvestment Rate over CEO Tenure}

This table reports the average of disinvestment rate, disinvestment rate conditional on there is disinvestment (no zeros), and the restructuring rate by CEO tenure ( $\mathrm{t}$ ) for the full sample and the exogenous turnover sample. The cumulative rates from year 0 to year 2 are also reported. "Disinvestment Rate" equals (value of asset sales + value of discontinued operations]/lagged net PPE. "Restructuring Rate" is the restructuring cost scaled by lagged net PPE.

\begin{tabular}{l|cccc}
\hline & \multicolumn{3}{|c}{ Disinvestment Rate } & $\begin{array}{c}\text { Disinvestment Rate } \\
\text { Conditional on } \\
\text { Disinvestment }\end{array}$ \\
Tenure & $\begin{array}{c}\text { Full } \\
\text { Sample }\end{array}$ & $\begin{array}{c}\text { Exogenous } \\
\text { Turnover }\end{array}$ & Full Sample & $\begin{array}{c}\text { Restructuring } \\
\text { Rate }\end{array}$ \\
\hline 0 & 0.046 & 0.042 & 0.232 & Full Sample \\
1 & 0.048 & 0.044 & 0.236 & 0.027 \\
2 & 0.047 & 0.062 & 0.238 & 0.027 \\
3 & 0.040 & 0.059 & 0.215 & 0.027 \\
4 & 0.043 & 0.053 & 0.236 & 0.028 \\
5 & 0.040 & 0.027 & 0.241 & 0.025 \\
6 & 0.036 & 0.028 & 0.222 & 0.021 \\
7 & 0.038 & 0.021 & 0.217 & 0.024 \\
8 & 0.030 & 0.028 & 0.192 & 0.014 \\
\hline cumulative & & & & 0.014 \\
{$[0,2]$} & 0.141 & 0.148 & 0.260 & 0.063 \\
\hline
\end{tabular}




\section{Table 3: Investment Rate and CEO Tenure}

\section{Panel A: Investment Trend over CEO Tenure}

This table reports the averages of various investment-related rates by CEO tenure year for the whole sample and the exogenous turnover sample. "Acquisition Rate" is the value of acquired assets divided by lagged net PPE. "Capx Rate" is capital expenditures divided by lagged net PPE. "Investment Rate" is the sum of acquisition and capital expenditures scaled by lagged net PPE.

\begin{tabular}{|c|c|c|c|c|c|c|}
\hline \multirow[b]{2}{*}{ Tenure } & \multicolumn{2}{|c|}{$\begin{array}{l}\text { Investment Rate } \\
\text { Exogenous }\end{array}$} & \multicolumn{2}{|c|}{$\begin{array}{r}\text { Acquisition Rate } \\
\text { Exogenous }\end{array}$} & \multicolumn{2}{|c|}{$\begin{array}{l}\text { Capx Rate } \\
\text { Exogenous }\end{array}$} \\
\hline & Full Sample & Turnover & Full Sample & Turnover & Full Sample & Turnover \\
\hline 0 & 0.533 & 0.470 & 0.223 & 0.223 & 0.310 & 0.248 \\
\hline 1 & 0.598 & 0.502 & 0.272 & 0.242 & 0.326 & 0.260 \\
\hline 2 & 0.647 & 0.486 & 0.328 & 0.240 & 0.319 & 0.246 \\
\hline 3 & 0.650 & 0.536 & 0.327 & 0.288 & 0.323 & 0.248 \\
\hline 4 & 0.689 & 0.567 & 0.360 & 0.293 & 0.328 & 0.274 \\
\hline 5 & 0.696 & 0.613 & 0.362 & 0.318 & 0.335 & 0.294 \\
\hline 6 & 0.684 & 0.610 & 0.349 & 0.347 & 0.335 & 0.263 \\
\hline 7 & 0.771 & 0.587 & 0.418 & 0.299 & 0.354 & 0.287 \\
\hline 8 & 0.745 & 0.537 & 0.411 & 0.240 & 0.335 & 0.297 \\
\hline
\end{tabular}




\section{Panel B: Investment Rate and CEO Tenure}

This table reports the trend in investment rate 1 over CEO tenure. Observations are at the firm-year level. Models (1) to (8) present results for the full sample as well as various subsamples for long-term CEOs (more than 6 years total time in office) and different turnover types. A constant term is included in all models but omitted for brevity. Other control variables except for Firm Age are lagged. Firm and Year Fixed effects are included in all models. The definitions of all variables are in Appendix A. The Huber-White-Sandwich robust standard errors are clustered by firm and reported in parenthesis. ***, ** and * indicate significance at the $1 \%, 5 \%$ and $10 \%$ levels respectively.

\begin{tabular}{|c|c|c|c|c|c|c|c|c|}
\hline & $\begin{array}{c}\text { (1) } \\
\text { Full Sample }\end{array}$ & $\begin{array}{c}(2) \\
\mathrm{Yr}[0,5], \text { long- } \\
\text { term CEO }\end{array}$ & $\begin{array}{c}\text { (3) } \\
\text { Full Sample }\end{array}$ & $\begin{array}{c}(4) \\
\text { Turnover } \\
\text { since } 1990\end{array}$ & $\begin{array}{c}(5) \\
\text { Long-term } \\
\text { CEO }\end{array}$ & $\begin{array}{c}(6) \\
\text { Insider } \\
\text { Successor }\end{array}$ & $\begin{array}{c}(7) \\
\text { Exogenous } \\
\text { Turnover }\end{array}$ & $\begin{array}{c}(8) \\
\text { Forced } \\
\text { Turnover }\end{array}$ \\
\hline & \multicolumn{8}{|c|}{ Investment Rate } \\
\hline $\begin{array}{l}\text { Tenure } \\
\text { (in years) }\end{array}$ & $\begin{array}{l}0.004 * \\
(0.003)\end{array}$ & $\begin{array}{c}0.020 * * \\
(0.010)\end{array}$ & & & & & & \\
\hline Years $[0,2]$ & & & $\begin{array}{c}-0.059 * * * \\
(0.016)\end{array}$ & $\begin{array}{c}-0.059 * * * \\
(0.020)\end{array}$ & $\begin{array}{c}-0.075 * * * \\
(0.024)\end{array}$ & $\begin{array}{c}-0.043 * * \\
(0.018)\end{array}$ & $\begin{array}{l}-0.014 \\
(0.036)\end{array}$ & $\begin{array}{c}-0.124 * * \\
(0.060)\end{array}$ \\
\hline CEO Age & $\begin{array}{c}-0.005 * * * \\
(0.002)\end{array}$ & $\begin{array}{l}-0.005 \\
(0.005)\end{array}$ & $\begin{array}{c}-0.005 * * * \\
(0.002)\end{array}$ & $\begin{array}{c}-0.006 * * * \\
(0.002)\end{array}$ & $\begin{array}{l}-0.005 * \\
(0.003)\end{array}$ & $\begin{array}{c}-0.006 * * * \\
(0.002)\end{array}$ & $\begin{array}{l}-0.001 \\
(0.003)\end{array}$ & $\begin{array}{l}-0.003 \\
(0.006)\end{array}$ \\
\hline Firm Age & $\begin{array}{l}-0.012 * \\
(0.007)\end{array}$ & $\begin{array}{c}0.012 \\
(0.101)\end{array}$ & $\begin{array}{l}-0.012 * \\
(0.007)\end{array}$ & $\begin{array}{l}-0.011 \\
(0.007)\end{array}$ & $\begin{array}{c}0.028 \\
(0.036)\end{array}$ & $\begin{array}{l}-0.013 * \\
(0.008)\end{array}$ & $\begin{array}{l}-0.010 \\
(0.015)\end{array}$ & $\begin{array}{l}-0.006 \\
(0.005)\end{array}$ \\
\hline $\begin{array}{l}\text { Ind-adj. } \\
\text { ROA }\end{array}$ & $\begin{array}{c}1.030 * * * \\
(0.133)\end{array}$ & $\begin{array}{c}1.180 * * * \\
(0.348)\end{array}$ & $\begin{array}{c}1.023 * * * \\
(0.133)\end{array}$ & $\begin{array}{c}1.042 * * * \\
(0.164)\end{array}$ & $\begin{array}{c}1.225 * * * \\
(0.176)\end{array}$ & $\begin{array}{c}1.292 * * * \\
(0.162)\end{array}$ & $\begin{array}{c}0.937^{*} \\
(0.547)\end{array}$ & $\begin{array}{l}-0.185 \\
(0.569)\end{array}$ \\
\hline $\begin{array}{l}\text { Ind-adj. } \\
\text { Return }\end{array}$ & $\begin{array}{c}0.093 * * * \\
(0.017)\end{array}$ & $\begin{array}{c}0.125 * * * \\
(0.042)\end{array}$ & $\begin{array}{c}0.093 * * * \\
(0.017)\end{array}$ & $\begin{array}{c}0.076^{* * *} \\
(0.019)\end{array}$ & $\begin{array}{c}0.108 * * * \\
(0.023)\end{array}$ & $\begin{array}{c}0.063 * * * \\
(0.020)\end{array}$ & $\begin{array}{c}0.131 * * * \\
(0.034)\end{array}$ & $\begin{array}{l}0.105 * \\
(0.054)\end{array}$ \\
\hline $\mathrm{MB}$ & $\begin{array}{c}0.017 * * * \\
(0.003)\end{array}$ & $\begin{array}{c}0.018 * * * \\
(0.007)\end{array}$ & $\begin{array}{c}0.017 * * * \\
(0.003)\end{array}$ & $\begin{array}{c}0.015 * * * \\
(0.004)\end{array}$ & $\begin{array}{c}0.018 * * * \\
(0.004)\end{array}$ & $\begin{array}{c}0.008 * * \\
(0.003)\end{array}$ & $\begin{array}{c}0.005 \\
(0.006)\end{array}$ & $\begin{array}{l}-0.004 \\
(0.009)\end{array}$ \\
\hline Leverage & $\begin{array}{c}-0.606 * * * \\
(0.073)\end{array}$ & $\begin{array}{c}-0.915 * * * \\
(0.201)\end{array}$ & $\begin{array}{c}-0.603 * * * \\
(0.073)\end{array}$ & $\begin{array}{c}-0.580 * * * \\
(0.094)\end{array}$ & $\begin{array}{c}-0.685 * * * \\
(0.094)\end{array}$ & $\begin{array}{c}-0.628 * * * \\
(0.092)\end{array}$ & $\begin{array}{c}-0.344 * * \\
(0.158)\end{array}$ & $\begin{array}{l}-0.762 * \\
(0.439)\end{array}$ \\
\hline Div. Payer & $\begin{array}{c}0.095 * * * \\
(0.031)\end{array}$ & $\begin{array}{l}-0.007 \\
(0.078)\end{array}$ & $\begin{array}{c}0.097 * * * \\
(0.031)\end{array}$ & $\begin{array}{c}0.082 * * \\
(0.038)\end{array}$ & $\begin{array}{l}0.073 * \\
(0.037)\end{array}$ & $\begin{array}{c}0.089 * * * \\
(0.034)\end{array}$ & $\begin{array}{l}-0.060 \\
(0.051)\end{array}$ & $\begin{array}{c}0.289 * * * \\
(0.101)\end{array}$ \\
\hline $\log$ (Assets) & $\begin{array}{c}-0.238 * * * \\
(0.024)\end{array}$ & $\begin{array}{c}-0.295 * * * \\
(0.053)\end{array}$ & $\begin{array}{c}-0.234 * * * \\
(0.024)\end{array}$ & $\begin{array}{c}-0.292 * * * \\
(0.035)\end{array}$ & $\begin{array}{c}-0.233 * * * \\
(0.030)\end{array}$ & $\begin{array}{c}-0.253 * * * \\
(0.028)\end{array}$ & $\begin{array}{l}-0.122^{*} \\
(0.067)\end{array}$ & $\begin{array}{l}-0.109 * \\
(0.056)\end{array}$ \\
\hline Obs. & 32,722 & 8,973 & 32,722 & 23,455 & 24,753 & 21,893 & 2,817 & 1,701 \\
\hline Adj. R-sqr. & 0.242 & 0.318 & 0.242 & 0.253 & 0.247 & 0.256 & 0.272 & 0.163 \\
\hline
\end{tabular}




\section{Panel C: Expansion Announcements and Segment Starts}

In Columns (1) and (2), the dependent variables are the downsizing announcement indicator $I_{\{\text {expansion announcement(s) in }}$ the month, and the observations are at the firm-month level. Expansion announcements are from the Capital IQ database and acquisition announcements are from SDC Platinum. The sample period is 2001-2009, since the Capital IQ coverage begins after 2000. "Months [0,24]" is an indicator variable that equals 1 for the first 24 months of a CEO's tenure, and 0 for later months. In Columns (3) and (4), the dependent variables are the segment start indicator $I_{\text {\{segment start\}. }}$. The data source is Compustat "historical segment" database. "Years $[0,2]$ " is an indicator variable that equals 1 for the first three years of a CEO's tenure, and 0 for later years. The definitions of all variables are in Appendix A. The Huber-White-Sandwich robust standard errors are clustered by firm and reported in parenthesis. $* * *, * *$ and $*$ indicate significance at the $1 \%, 5 \%$ and $10 \%$ levels respectively.

\begin{tabular}{|c|c|c|c|c|}
\hline & \multicolumn{2}{|c|}{$I_{\{\text {expansion announcement(s) in the month }\}}$} & \multicolumn{2}{|c|}{$I_{\{\text {segment start\} }}$} \\
\hline & (1) & (2) & (3) & (4) \\
\hline & Full Sample & $\begin{array}{l}\text { Exogenous } \\
\text { Turnover }\end{array}$ & Full Sample & $\begin{array}{c}\text { Exogenous } \\
\text { Turnover }\end{array}$ \\
\hline \multirow[t]{2}{*}{ Months $[0,24]$} & $-0.013 *$ & $-0.008 *$ & & \\
\hline & $(0.007)$ & $(0.005)$ & & \\
\hline \multirow[t]{2}{*}{ Years $[0,2]$} & & & $-0.008 *$ & $-0.006^{*}$ \\
\hline & & & $(0.005)$ & $(0.003)$ \\
\hline \multirow[t]{2}{*}{ CEO Age } & $-0.0001 *$ & 0.0001 & 0.001 & 0.0001 \\
\hline & $(0.0001)$ & $(0.0004)$ & $(0.001)$ & $(0.001)$ \\
\hline \multirow[t]{2}{*}{ Firm Age } & -0.0002 & $-0.001 *$ & 0.210 & -0.013 \\
\hline & $(0.0001)$ & -0.0004 & $(0.022)$ & $(0.015)$ \\
\hline \multirow[t]{2}{*}{ Ind-adj. ROA } & 0.001 & 0.013 & $0.038^{*}$ & 0.027 \\
\hline & $(0.006)$ & $(0.017)$ & $(0.021)$ & $(0.069)$ \\
\hline \multirow[t]{2}{*}{ Ind-adj. Return } & $0.002 * * *$ & $0.007 * * *$ & 0.005 & $0.029 * * *$ \\
\hline & $(0.001)$ & $(0.002)$ & $(0.004)$ & $(0.008)$ \\
\hline \multirow[t]{2}{*}{ MB } & -0.0001 & -0.001 & -0.0002 & 0.002 \\
\hline & $(0.0002)$ & $(0.001)$ & $(0.001)$ & $(0.002)$ \\
\hline \multirow[t]{2}{*}{ Leverage } & $-0.023 * * *$ & -0.030 & 0.007 & $0.045^{* *}$ \\
\hline & $(0.005)$ & $(0.019)$ & $(0.013)$ & $(0.021)$ \\
\hline \multirow[t]{2}{*}{ Div. Payer } & 0.001 & 0.003 & -0.018 & $0.164^{* *}$ \\
\hline & $(0.004)$ & $(0.010)$ & $(0.022)$ & $(0.077)$ \\
\hline \multirow[t]{2}{*}{$\log$ (Assets) } & $0.010 * * *$ & 0.006 & $0.013 *$ & -0.025 \\
\hline & $(0.002)$ & $(0.007)$ & $(0.007)$ & $(0.018)$ \\
\hline \multirow[t]{2}{*}{ \# of Segments } & & & $-0.032 * * *$ & $-0.089 * * *$ \\
\hline & & & $(0.003)$ & $(0.008)$ \\
\hline \multirow[t]{2}{*}{ Constant } & $-0.046^{* *}$ & 0.007 & 0.167 & $0.990 *$ \\
\hline & $(0.020)$ & $(0.052)$ & $(0.143)$ & $(0.585)$ \\
\hline \multicolumn{5}{|l|}{ Firm and Year } \\
\hline F.E. & $\mathrm{x}$ & $\mathrm{x}$ & $\mathrm{x}$ & $\mathrm{x}$ \\
\hline Obs. & 209,736 & 42,072 & 144,287 & 15,484 \\
\hline Adj. R-sqr. & 0.173 & 0.198 & 0.136 & 0.277 \\
\hline
\end{tabular}


Table 4: Net Effects CEO Tenure on Disinvestment and Investment

Panel A: Asset Growth Rate and CEO Tenure

This table reports the trend in the asset growth rate over CEO tenure. Models (1) to (8) present results for the full sample as well as various subsamples for longterm CEOs (more than 6 years total time in office) and different turnover types. A constant term is included in all models. Other control variables except for Firm Age are lagged. Firm and Year Fixed effects are included in all models. The definitions of all variables are in Appendix A. The Huber-White-Sandwich robust standard errors are clustered by firm and reported in parenthesis. $* * *, * *$ and $*$ indicate significance at the $1 \%, 5 \%$ and $10 \%$ levels respectively.

\begin{tabular}{|c|c|c|c|c|c|c|c|c|}
\hline & $\begin{array}{c}\text { (1) } \\
\text { Full Sample }\end{array}$ & $\begin{array}{c}(2) \\
\text { Yr }[0,5], \text { long- } \\
\text { term CEO }\end{array}$ & $\begin{array}{c}\text { (3) } \\
\text { Full Sample }\end{array}$ & $\begin{array}{c}(4) \\
\text { Turnover } \\
\text { since } 1992\end{array}$ & $\begin{array}{c}(5) \\
\text { Long-term } \\
\text { CEO }\end{array}$ & $\begin{array}{c}(6) \\
\text { Insider } \\
\text { Successor }\end{array}$ & $\begin{array}{c}(7) \\
\text { Exogenous } \\
\text { Turnover }\end{array}$ & $\begin{array}{c}(8) \\
\text { Forced } \\
\text { Turnover }\end{array}$ \\
\hline & \multicolumn{8}{|c|}{ Asset Growth Rate } \\
\hline $\begin{array}{l}\text { Tenure } \\
\text { (in years) }\end{array}$ & $\begin{array}{c}0.006 * * * \\
(0.001)\end{array}$ & $\begin{array}{c}0.018 * * * \\
(0.004)\end{array}$ & & & & & & \\
\hline Years $[0,2]$ & & & $\begin{array}{c}-0.032 * * * \\
(0.006)\end{array}$ & $\begin{array}{c}-0.026 * * * \\
(0.008)\end{array}$ & $\begin{array}{c}-0.040 * * * \\
(0.009)\end{array}$ & $\begin{array}{c}-0.025 * * * \\
(0.006)\end{array}$ & $\begin{array}{l}-0.017 * \\
(0.009)\end{array}$ & $\begin{array}{l}-0.028^{*} \\
(0.016)\end{array}$ \\
\hline CEO Age & $\begin{array}{c}-0.002 * * * \\
(0.001)\end{array}$ & $\begin{array}{l}-0.002 \\
(0.002)\end{array}$ & $\begin{array}{l}-0.000 \\
(0.001)\end{array}$ & $\begin{array}{c}0.001 \\
(0.001)\end{array}$ & $\begin{array}{c}0.000 \\
(0.001)\end{array}$ & $\begin{array}{c}0.000 \\
(0.001)\end{array}$ & $\begin{array}{l}-0.002 \\
(0.003)\end{array}$ & $\begin{array}{c}0.001 \\
(0.003)\end{array}$ \\
\hline Firm Age & $\begin{array}{l}-0.004 \\
(0.003)\end{array}$ & $\begin{array}{l}-0.084 \\
(0.222)\end{array}$ & $\begin{array}{c}-0.004 \\
(0.003)\end{array}$ & $\begin{array}{l}-0.028 \\
(0.029)\end{array}$ & $\begin{array}{l}-0.012 \\
(0.019)\end{array}$ & $\begin{array}{l}-0.004 \\
(0.003)\end{array}$ & $\begin{array}{c}-0.026^{* *} \\
(0.012)\end{array}$ & $\begin{array}{c}-0.009 * * * \\
(0.003)\end{array}$ \\
\hline $\begin{array}{l}\text { Ind-adj. } \\
\text { ROA }\end{array}$ & $\begin{array}{c}0.266^{* * * *} \\
(0.065)\end{array}$ & $\begin{array}{c}0.137 \\
(0.186)\end{array}$ & $\begin{array}{c}0.267 * * * \\
(0.065)\end{array}$ & $\begin{array}{c}0.321 * * * \\
(0.088)\end{array}$ & $\begin{array}{c}0.283 * * * \\
(0.086)\end{array}$ & $\begin{array}{c}0.263 * * * \\
(0.091)\end{array}$ & $\begin{array}{c}0.106 \\
(0.203)\end{array}$ & $\begin{array}{l}-0.177 \\
(0.370)\end{array}$ \\
\hline $\begin{array}{l}\text { Ind-adj. } \\
\text { Return }\end{array}$ & $\begin{array}{c}0.055 * * * \\
(0.007)\end{array}$ & $\begin{array}{c}0.052 * * * \\
(0.013)\end{array}$ & $\begin{array}{c}0.055^{* * *} \\
(0.007)\end{array}$ & $\begin{array}{c}0.049 * * * \\
(0.008)\end{array}$ & $\begin{array}{c}0.058 * * * \\
(0.008)\end{array}$ & $\begin{array}{c}0.048 * * * \\
(0.008)\end{array}$ & $\begin{array}{c}0.033 * * \\
(0.015)\end{array}$ & $\begin{array}{l}0.026 * \\
(0.016)\end{array}$ \\
\hline MB & $\begin{array}{c}0.013 * * * \\
(0.002)\end{array}$ & $\begin{array}{c}0.015 * * * \\
(0.003)\end{array}$ & $\begin{array}{c}0.013 * * * \\
(0.002)\end{array}$ & $\begin{array}{c}0.012 * * * \\
(0.002)\end{array}$ & $\begin{array}{c}0.014 * * * \\
(0.002)\end{array}$ & $\begin{array}{c}0.010 * * * \\
(0.002)\end{array}$ & $\begin{array}{c}0.002 \\
(0.003)\end{array}$ & $\begin{array}{l}0.019 * \\
(0.011)\end{array}$ \\
\hline Leverage & $\begin{array}{c}-0.269 * * * \\
(0.031)\end{array}$ & $\begin{array}{c}-0.360 * * * \\
(0.083)\end{array}$ & $\begin{array}{c}-0.269 * * * \\
(0.031)\end{array}$ & $\begin{array}{c}-0.185 * * * \\
(0.045)\end{array}$ & $\begin{array}{c}-0.329 * * * \\
(0.039)\end{array}$ & $\begin{array}{c}-0.288 * * * \\
(0.038)\end{array}$ & $\begin{array}{c}0.023 \\
(0.191)\end{array}$ & $\begin{array}{c}-0.325 * * * \\
(0.114)\end{array}$ \\
\hline Div. Payer & $\begin{array}{c}0.046 * * * \\
(0.013)\end{array}$ & $\begin{array}{l}0.048 * \\
(0.028)\end{array}$ & $\begin{array}{c}0.048 * * * \\
(0.013)\end{array}$ & $\begin{array}{c}0.044 * * * \\
(0.015)\end{array}$ & $\begin{array}{c}0.044 * * * \\
(0.016)\end{array}$ & $\begin{array}{c}0.053 * * * \\
(0.014)\end{array}$ & $\begin{array}{l}-0.024 \\
(0.056)\end{array}$ & $\begin{array}{l}-0.032 \\
(0.087)\end{array}$ \\
\hline $\log ($ Assets $)$ & $\begin{array}{c}-0.209 * * * \\
(0.011)\end{array}$ & $\begin{array}{c}-0.350 * * * \\
(0.035)\end{array}$ & $\begin{array}{c}-0.206 * * * \\
(0.010)\end{array}$ & $\begin{array}{c}-0.265 * * * \\
(0.014)\end{array}$ & $\begin{array}{c}-0.215 * * * \\
(0.013)\end{array}$ & $\begin{array}{c}-0.193 * * * \\
(0.012)\end{array}$ & $\begin{array}{l}-0.132 * \\
(0.069)\end{array}$ & $\begin{array}{c}-0.188 * * * \\
(0.050)\end{array}$ \\
\hline Obs. & 33,186 & 9,089 & 33,186 & 21,169 & 25,114 & 22,146 & 2,856 & 1,720 \\
\hline Adj. R-sqr. & 0.197 & 0.311 & 0.196 & 0.221 & 0.201 & 0.179 & 0.033 & 0.191 \\
\hline
\end{tabular}




\section{Panel B: Employment Growth Rate and CEO Tenure}

This table reports the trend in the sales growth rate over CEO tenure. Models (1) to (8) present results for the full sample as well as various subsamples for longterm CEOs (more than 6 years total time in office) and different turnover types. A constant term is included in all models but omitted for brevity. Other control variables except for Firm Age are lagged. Firm and Year Fixed effects are included in all models. The definitions of all variables are in Appendix A. The HuberWhite-Sandwich robust standard errors are clustered by firm and reported in parenthesis. ***, ** and * indicate significance at the $1 \%, 5 \%$ and $10 \%$ levels respectively.

\begin{tabular}{|c|c|c|c|c|c|c|c|c|}
\hline & $\begin{array}{c}\text { (1) } \\
\text { Full Sample }\end{array}$ & $\begin{array}{c}(2) \\
\mathrm{Yr}[0,5], \text { long- } \\
\text { term CEO }\end{array}$ & $\begin{array}{c}\text { (3) } \\
\text { Full Sample }\end{array}$ & $\begin{array}{c}(4) \\
\text { Turnover } \\
\text { since } 1992\end{array}$ & $\begin{array}{c}(5) \\
\text { Long-term } \\
\text { CEO }\end{array}$ & $\begin{array}{c}\text { (6) } \\
\text { Insider } \\
\text { Successor }\end{array}$ & $\begin{array}{c}(7) \\
\text { Exogenous } \\
\text { Turnover }\end{array}$ & $\begin{array}{c}(8) \\
\text { Forced } \\
\text { Turnover }\end{array}$ \\
\hline & \multicolumn{8}{|c|}{ Employment Growth Rate } \\
\hline $\begin{array}{l}\text { Tenure } \\
\text { (in years) }\end{array}$ & $\begin{array}{c}0.004 * * * \\
(0.001)\end{array}$ & $\begin{array}{c}0.007 * * * \\
(0.003)\end{array}$ & & & & & & \\
\hline Years $[0,2]$ & & & $\begin{array}{c}-0.022 * * * \\
(0.004)\end{array}$ & $\begin{array}{c}-0.020 * * * \\
(0.006)\end{array}$ & $\begin{array}{c}-0.022 * * * \\
(0.006)\end{array}$ & $\begin{array}{c}-0.014 * * * \\
(0.005)\end{array}$ & $\begin{array}{l}-0.007 * \\
(0.004)\end{array}$ & $\begin{array}{l}-0.016 * \\
(0.010)\end{array}$ \\
\hline CEO Age & $\begin{array}{c}-0.002 * * * \\
(0.000)\end{array}$ & $\begin{array}{c}-0.002 * * \\
(0.001)\end{array}$ & $\begin{array}{c}-0.001 * * * \\
(0.000)\end{array}$ & $\begin{array}{l}-0.000 \\
(0.001)\end{array}$ & $\begin{array}{c}-0.001 * * \\
(0.000)\end{array}$ & $\begin{array}{c}-0.001 * * \\
(0.000)\end{array}$ & $\begin{array}{l}-0.000 \\
(0.001)\end{array}$ & $\begin{array}{c}0.004 \\
(0.003)\end{array}$ \\
\hline Firm Age & $\begin{array}{l}-0.003 \\
(0.003)\end{array}$ & $\begin{array}{l}-0.188 \\
(0.145)\end{array}$ & $\begin{array}{l}-0.003 \\
(0.003)\end{array}$ & $\begin{array}{l}-0.030 \\
(0.027)\end{array}$ & $\begin{array}{l}-0.013 \\
(0.013)\end{array}$ & $\begin{array}{l}-0.003 \\
(0.003)\end{array}$ & $\begin{array}{c}-0.018 * * \\
(0.009)\end{array}$ & $\begin{array}{l}-0.004 * \\
(0.002)\end{array}$ \\
\hline $\begin{array}{l}\text { Ind-adj. } \\
\text { ROA }\end{array}$ & $\begin{array}{c}0.221 * * * \\
(0.032)\end{array}$ & $\begin{array}{l}0.187 * * \\
(0.087)\end{array}$ & $\begin{array}{c}0.221 * * * \\
(0.032)\end{array}$ & $\begin{array}{c}0.205 * * * \\
(0.046)\end{array}$ & $\begin{array}{c}0.213 * * * \\
(0.041)\end{array}$ & $\begin{array}{c}0.218 * * * \\
(0.044)\end{array}$ & $\begin{array}{c}0.108 \\
(0.097)\end{array}$ & $\begin{array}{c}0.013 \\
(0.204)\end{array}$ \\
\hline $\begin{array}{l}\text { Ind-adj. } \\
\text { Return }\end{array}$ & $\begin{array}{c}0.028 * * * \\
(0.004)\end{array}$ & $\begin{array}{c}0.030 * * * \\
(0.008)\end{array}$ & $\begin{array}{c}0.028 * * * \\
(0.004)\end{array}$ & $\begin{array}{c}0.026^{* * *} \\
(0.004)\end{array}$ & $\begin{array}{c}0.032 * * * \\
(0.005)\end{array}$ & $\begin{array}{c}0.027 * * * \\
(0.005)\end{array}$ & $\begin{array}{c}0.020 * * \\
(0.009)\end{array}$ & $\begin{array}{c}0.018 * * \\
(0.009)\end{array}$ \\
\hline $\mathrm{MB}$ & $\begin{array}{c}0.004 * * * \\
(0.001)\end{array}$ & $\begin{array}{l}0.003 * \\
(0.002)\end{array}$ & $\begin{array}{c}0.004 * * * \\
(0.001)\end{array}$ & $\begin{array}{c}0.003 * * * \\
(0.001)\end{array}$ & $\begin{array}{c}0.003 * * * \\
(0.001)\end{array}$ & $\begin{array}{l}0.002 * * \\
(0.001)\end{array}$ & $\begin{array}{c}0.002 \\
(0.001)\end{array}$ & $\begin{array}{l}0.005 * * \\
(0.002)\end{array}$ \\
\hline Leverage & $\begin{array}{c}-0.144 * * * \\
(0.022)\end{array}$ & $\begin{array}{c}-0.209 * * * \\
(0.056)\end{array}$ & $\begin{array}{c}-0.144 * * * \\
(0.022)\end{array}$ & $\begin{array}{c}-0.112 * * * \\
(0.032)\end{array}$ & $\begin{array}{c}-0.179 * * * \\
(0.026)\end{array}$ & $\begin{array}{c}-0.159 * * * \\
(0.023)\end{array}$ & $\begin{array}{l}-0.035 \\
(0.066)\end{array}$ & $\begin{array}{c}-0.160 * * \\
(0.081)\end{array}$ \\
\hline Div. Payer & $\begin{array}{l}0.017 * \\
(0.010)\end{array}$ & $\begin{array}{c}0.026 \\
(0.026)\end{array}$ & $\begin{array}{c}0.019 * * \\
(0.010)\end{array}$ & $\begin{array}{c}0.020 \\
(0.013)\end{array}$ & $\begin{array}{c}0.016 \\
(0.011)\end{array}$ & $\begin{array}{l}0.021 * \\
(0.011)\end{array}$ & $\begin{array}{c}0.037 \\
(0.035)\end{array}$ & $\begin{array}{l}-0.052 \\
(0.042)\end{array}$ \\
\hline $\log$ (Assets) & $\begin{array}{c}-0.103 * * * \\
(0.006)\end{array}$ & $\begin{array}{c}-0.149 * * * \\
(0.017)\end{array}$ & $\begin{array}{c}-0.101 * * * \\
(0.006)\end{array}$ & $\begin{array}{c}-0.127 * * * \\
(0.009)\end{array}$ & $\begin{array}{c}-0.107 * * * \\
(0.007)\end{array}$ & $\begin{array}{c}-0.101 * * * \\
(0.008)\end{array}$ & $\begin{array}{c}-0.111 * * * \\
(0.024)\end{array}$ & $\begin{array}{c}-0.107 * * * \\
(0.025)\end{array}$ \\
\hline Obs. & 32,370 & 8,832 & 32,370 & 20,765 & 24,451 & 21,651 & 2,823 & 1,688 \\
\hline Adj. R-sqr. & 0.177 & 0.263 & 0.176 & 0.163 & 0.188 & 0.186 & 0.110 & 0.191 \\
\hline
\end{tabular}




\section{Table 5: Comparing the Magnitude of the CEO Cycle with Other Factors Affecting Investment}

This table compares the estimation coefficients of the CEO cycle (First 3 years vs. later) with other external factors that affects firm's investment: business cycle (Recession vs. non-recession, see results presented in Appendix B1), political cycle (Election vs. non-election, see Julio and Yook, 2012), and financial constraints (One std. dev. increase in financial constraint during 2008-2009, see Ball, Hoberg, and Maksimovic, 2013). I/K, I/A, and I/S are Capital Expenditure scaled by lagged (beginning-of-period) PPE, lagged Assets, and Sales, respectively.

\begin{tabular}{|c|c|c|c|}
\hline & $\mathrm{I} / \mathrm{K}$ & $\mathrm{I} / \mathrm{A}$ & $\mathrm{I} / \mathrm{S}$ \\
\hline CEO's first 3 years vs. later & $-2.3 \mathrm{pts}$ & $-1.0 \mathrm{pts}$ & $-0.4 \mathrm{pts}$ \\
\hline Recession vs. non-recession (Table B1) & $-2.8 \mathrm{pts}$ & & \\
\hline $\begin{array}{l}\text { Election vs. non-election (Julio and Yook, 2012) } \\
\text { One std. dev. increase in financial constraint during } \\
\text { 2008-2009 (Ball, Hoberg, and Maksimovic, 2013) }\end{array}$ & & $-0.4 \mathrm{pts}$ & 0 to $-0.8 \mathrm{pts}$ \\
\hline
\end{tabular}




\section{Table 6: Agency Explanations for the Disinvestment Cycle}

\section{Panel A: Segment Termination}

This table reports the OLS estimation of the probability of a segment being terminated, using the segment data from Compustat "historical segment" data base, for multi-segment firm(-year)s in our sample. The dependent variable is an indicator variable that equals 1 if the segment is divested or discontinued. The observations are at the segment-year level for the entire life of each segment. In model (1) and (3), we control for industry-year fixed effects. In models (2) and (4), we control for firm-year fixed effects. In models (3) and (4), we use the subsample with original CEOs replaced (if replaced) after exogenous turnovers. All variables definitions are in Appendix A. The estimated coefficients are reported first, followed by the standard errors, then the marginal effects (in square brackets). $* * *, * *$ and $*$ indicate significance at the $1 \%, 5 \%$, and $10 \%$ levels respectively.
(1)
(2)
(3)

(4)

Exogenous Turnovers

\begin{tabular}{lcccc} 
Original CEO Replaced & -0.004 & -0.013 & -0.003 & -0.012 \\
& $(0.003)$ & $(0.010)$ & $(0.009)$ & $(0.010)$ \\
Original CEO Replaced & $0.073^{* * *}$ & $0.060^{* * *}$ & $0.076^{*}$ & $0.082^{* *}$ \\
x Underperforming Segment & $(0.023)$ & $(0.021)$ & $(0.045)$ & $(0.032)$ \\
Underperforming Segment & 0.021 & 0.016 & -0.025 & 0.022 \\
& $(0.018)$ & $(0.016)$ & $(0.031)$ & $(0.021)$ \\
Segment Age & $-0.001 * * *$ & $-0.001 * * *$ & $-0.002 * * *$ & $-0.003^{* * *}$ \\
& $(0.0001)$ & $(0.0001)$ & $(0.0003)$ & $(0.0004)$ \\
Constant & $0.044^{* * *}$ & $0.058^{* * *}$ & $0.069^{* * *}$ & $0.079^{* * *}$ \\
& $(0.003)$ & $(0.005)$ & $(0.007)$ & $(0.006)$ \\
Industry-Year F.E. & $\mathrm{X}$ & & $\mathrm{x}$ & \\
Firm-Year F.E. & & $\mathrm{x}$ & & $\mathrm{x}$ \\
Obs. & 128,961 & 128,961 & 14,186 & 14,186 \\
Adj. R-sqr. & 0.070 & 0.290 & 0.197 & 0.255 \\
\hline
\end{tabular}




\section{Panel B: Residual Influence of Old CEO on Post-Turnover Downsizing}

This table reports the effect of residual influence from old management on segment termination, using the segment data from Compustat "historical segment" data base, for multi-segment firm(-year)s in our sample. Information on "\% On Board [old mgt.]" is from the director (and director-legacy) data base from RiskMetrics, which starts from 1996. Information on "Classified Board" is from the governance (and governance-legacy) data base from RiskMetrics, which starts from 1990. The dependent variable is an indicator variable that equals 1 if the segment is divested or discontinued. The observations are at the segment-year level for the entire life of each segment. In all models, we control for firm-year fixed effects and use the first three years after the original CEO was replaced ("under new regime"). All variables definitions are in Appendix A. The Huber-White-Sandwich robust standard errors are clustered by firm and reported in parenthesis. ${ }^{* *}, * *$ and $*$ indicate significance at the $1 \%, 5 \%$ and $10 \%$ levels respectively.

\begin{tabular}{|c|c|c|c|c|}
\hline & \multicolumn{4}{|c|}{$\begin{array}{c}I_{\{\text {segment termination\} }} \\
\text { Under new regime in years }[0,2]\end{array}$} \\
\hline & $(1)$ & $(2)$ & $(3)$ & $(4)$ \\
\hline Underperforming Segment & $\begin{array}{l}0.115 * * * \\
(0.011)\end{array}$ & $\begin{array}{c}0.117 * * * \\
(0.015)\end{array}$ & $\begin{array}{c}0.085^{* * *} \\
(0.007)\end{array}$ & $\begin{array}{c}0.096 * * * \\
(0.009)\end{array}$ \\
\hline Stay as Chairman $\mathrm{x}$ Underperforming Segment & $\begin{array}{c}-0.027^{*} \\
(0.015)\end{array}$ & & & \\
\hline$\%$ of Old Mgmt. On Board x Underperforming Segment & & $\begin{array}{c}-0.094 * * \\
(0.041)\end{array}$ & & \\
\hline Outsider Succession x Underperforming Segment & & & $\begin{array}{l}0.039 * * \\
(0.016)\end{array}$ & \\
\hline Classified Board x Underperforming Segment & & & & $\begin{array}{c}-0.018 * * \\
(0.009)\end{array}$ \\
\hline Segment Age & $\begin{array}{c}-0.003 * * * \\
(0.000)\end{array}$ & $\begin{array}{c}-0.003 * * * \\
(0.000)\end{array}$ & $\begin{array}{c}-0.003 * * * \\
(0.000)\end{array}$ & $\begin{array}{c}-0.002 * * * \\
(0.000)\end{array}$ \\
\hline Constant & $\begin{array}{c}0.082 * * * \\
(0.003)\end{array}$ & $\begin{array}{c}0.076^{* * *} \\
(0.004)\end{array}$ & $\begin{array}{c}0.076^{* * *} \\
(0.003)\end{array}$ & $\begin{array}{c}0.063 * * * \\
(0.002)\end{array}$ \\
\hline Firm-Year F.E. & $\mathrm{x}$ & $\mathrm{x}$ & $\mathrm{x}$ & $\mathrm{x}$ \\
\hline Obs. & 22,250 & 18,733 & 42,123 & 31,627 \\
\hline Adj. R-sqr. & 0.295 & 0.269 & 0.298 & 0.283 \\
\hline
\end{tabular}




\section{Table 7: CEO Investment Cycles in Single-Segment Firms}

This table reports the trend in probability of disinvestment and the rate of investment over CEO tenure for single segment firms. Models (1) and (2) report results for the subsample of firms with only one segment (defined by segment ID in Compustat (historical) segment data base) at the CEO turnover year. Models (3) and (4) report results for single-segment firms that hired company insiders or industry insiders as the CEOs. All explanatory variables except for time/age related variables are lagged by one year. The definitions of all variables are in Appendix A. The Huber-White-Sandwich robust standard errors are clustered by firm and reported in parenthesis. ***, ** and * indicate significance at the $1 \%, 5 \%$ and $10 \%$ levels respectively.

\begin{tabular}{|c|c|c|c|c|}
\hline & $\begin{array}{l}(1) \\
I_{\text {\{asset sales }>0 \text { or discontinued }} \\
\text { operations }>0\} \\
\text { Single-Segm }\end{array}$ & $\begin{array}{l}(2) \\
\text { Investment } \\
\text { Rate }\end{array}$ & $\begin{array}{c}(3) \\
I_{\{\text {asset sales }>0 \text { or discontinued }} \\
\text { operations }>0\} \\
\text { Single-Segment, Compa } \\
\text { Success }\end{array}$ & $\begin{array}{l}\text { (4) } \\
\text { Investment } \\
\text { Rate } \\
\text { ustry Insider }\end{array}$ \\
\hline Years $[0,2]$ & $\begin{array}{c}0.022 * * \\
(0.010)\end{array}$ & $\begin{array}{l}-0.062 * \\
(0.033)\end{array}$ & $\begin{array}{c}0.027 * * \\
(0.012)\end{array}$ & $\begin{array}{l}-0.046^{*} \\
(0.025)\end{array}$ \\
\hline CEO Age & $\begin{array}{l}-0.001 \\
(0.001)\end{array}$ & $\begin{array}{l}-0.007 \\
(0.005)\end{array}$ & $\begin{array}{c}0.001 \\
(0.001)\end{array}$ & $\begin{array}{l}-0.007 \\
(0.005)\end{array}$ \\
\hline Firm Age & $\begin{array}{l}-0.000 \\
(0.001)\end{array}$ & $\begin{array}{l}-0.012 \\
(0.011)\end{array}$ & $\begin{array}{c}0.001 \\
(0.001)\end{array}$ & $\begin{array}{l}-0.011 \\
(0.011)\end{array}$ \\
\hline Ind-adj. ROA & $\begin{array}{c}-0.132 * * * \\
(0.028)\end{array}$ & $\begin{array}{c}1.011^{* * *} \\
(0.220)\end{array}$ & $\begin{array}{c}-0.171 * * * \\
(0.041)\end{array}$ & $\begin{array}{c}1.262 * * * \\
(0.246)\end{array}$ \\
\hline Ind-adj. Return & $\begin{array}{l}-0.002 \\
(0.004)\end{array}$ & $\begin{array}{c}0.107 * * * \\
(0.029)\end{array}$ & $\begin{array}{c}0.002 \\
(0.005)\end{array}$ & $\begin{array}{c}0.066^{* *} \\
(0.033)\end{array}$ \\
\hline MB & $\begin{array}{l}-0.000 \\
(0.001)\end{array}$ & $\begin{array}{c}0.019 * * * \\
(0.006)\end{array}$ & $\begin{array}{l}-0.001 \\
(0.001)\end{array}$ & $\begin{array}{c}0.006 \\
(0.005)\end{array}$ \\
\hline Leverage & $\begin{array}{l}-0.026 \\
(0.021)\end{array}$ & $\begin{array}{l}-0.020 \\
(0.065)\end{array}$ & $\begin{array}{l}-0.033 \\
(0.026)\end{array}$ & $\begin{array}{l}-0.034 \\
(0.064)\end{array}$ \\
\hline Div. Payer & $\begin{array}{l}-0.009 \\
(0.031)\end{array}$ & $\begin{array}{c}-0.657 * * * \\
(0.135)\end{array}$ & $\begin{array}{l}-0.003 \\
(0.040)\end{array}$ & $\begin{array}{c}-0.867 * * * \\
(0.153)\end{array}$ \\
\hline $\log$ (Assets) & $\begin{array}{c}0.016 \\
(0.010)\end{array}$ & $\begin{array}{c}-0.272 * * * \\
(0.051)\end{array}$ & $\begin{array}{c}0.012 \\
(0.012)\end{array}$ & $\begin{array}{c}-0.304 * * * \\
(0.055)\end{array}$ \\
\hline Constant & $\begin{array}{l}0.203^{*} \\
(0.121)\end{array}$ & $\begin{array}{c}3.324 * * * \\
(0.626)\end{array}$ & $\begin{array}{c}0.052 \\
(0.134)\end{array}$ & $\begin{array}{c}3.672 * * * \\
(0.680)\end{array}$ \\
\hline $\begin{array}{l}\text { Firm and Year } \\
\text { F.E. }\end{array}$ & $\mathrm{x}$ & $\mathrm{x}$ & $\mathrm{x}$ & $\mathrm{x}$ \\
\hline Obs & 10,826 & 10,685 & 8,219 & 8,111 \\
\hline Adj. R-sqr. & 0.235 & 0.256 & 0.223 & 0.250 \\
\hline
\end{tabular}




\section{Table 8: Agency Explanations for the Investment Cycle}

\section{Panel A: Percentage of New Directors Appointed by the CEO}

This table reports the determinants of the percentage of new directors appointed by the incumbent CEO, including the time-varying CEO tenure, some proxy variables for CEO power, and lagged firm size and performance measures. The director related variables are constructed using RiskMetrics data which stars from 1996. The definitions of all variables are in Appendix A. The Huber-White-Sandwich robust standard errors are clustered by firm and reported in parenthesis. ${ }^{* *}, * *$ and $*$ indicate significance at the $1 \%, 5 \%$ and $10 \%$ levels respectively.

\begin{tabular}{lcc}
\hline & $(1)$ & $(2)$ \\
& $\%$ of New Directors \\
\hline & & \\
Tenure (in years) & $0.045^{* * *}$ & $0.048^{* * *}$ \\
& $(0.001)$ & $(0.001)$ \\
CEO Ownership & & 0.096 \\
& & $(0.087)$ \\
CEO is the Chairman of the Board & $0.028^{* * *}$ \\
& & $(0.006)$ \\
log(Assets) & & $-0.053^{* * *}$ \\
& & $(0.007)$ \\
Ind-adj. ROA & & -0.057 \\
& & $(0.050)$ \\
Ind-adj. Return & & $0.117^{* * *}$ \\
& & $(0.043)$ \\
Constant & $0.226^{* * *}$ & $0.595^{* * *}$ \\
& $(0.005)$ & $(0.053)$ \\
Firm F.E. & $\mathrm{X}$ & $\mathrm{x}$ \\
Obs. & 16,220 & 11,199 \\
Adj. R-sqr. & 0.779 & 0.803 \\
\hline
\end{tabular}


Panel B: CEO Capture of the Board and Investment

This table reports the effect of the percentage of directors appointed during the incumbent CEO's tenure on various investment, growth, and disinvestment variables. Control variables except for Firm Age are lagged. Firm and Year Fixed effects are included in all models. The definitions of all variables are in Appendix A. The Huber-WhiteSandwich robust standard errors are clustered by firm and reported in parenthesis. $* * *, * *$ and $*$ indicate significance at the $1 \%, 5 \%$ and $10 \%$ levels respectively.

\begin{tabular}{|c|c|c|c|c|c|c|}
\hline & $\begin{array}{c}(1) \\
\text { Investment } \\
\text { Rate }\end{array}$ & $\begin{array}{c}(2) \\
\text { CapEx } \\
\text { Rate }\end{array}$ & $\begin{array}{c}\text { (3) } \\
\text { Acquisition } \\
\text { Rate }\end{array}$ & $\begin{array}{c}\text { (4) } \\
\text { Asset } \\
\text { Growth Rate }\end{array}$ & $\begin{array}{l}\text { (5) } \\
\text { Employment } \\
\text { Growth Rate }\end{array}$ & $\begin{array}{c}\text { (6) } \\
\mathrm{I}_{\{\text {asset sales }>0 \text { or }} \\
\text { discontinued } \\
\text { operations }>0\} \\
\end{array}$ \\
\hline Years $[0,2]$ & $\begin{array}{l}-0.003 \\
(0.037)\end{array}$ & $\begin{array}{c}-0.008 \\
(0.007)\end{array}$ & $\begin{array}{c}0.005 \\
(0.036)\end{array}$ & $\begin{array}{l}-0.004 \\
(0.011)\end{array}$ & $\begin{array}{c}-0.016 * * \\
(0.007)\end{array}$ & $\begin{array}{c}0.034 * * * \\
(0.012)\end{array}$ \\
\hline$\%$ of New & $0.333 * * *$ & $0.066 * * *$ & $0.267 * *$ & $0.076 * * *$ & 0.009 & -0.004 \\
\hline Directors & $(0.129)$ & $(0.024)$ & $(0.124)$ & $(0.025)$ & $(0.016)$ & $(0.022)$ \\
\hline CEO Age & $\begin{array}{c}0.005 \\
(0.016)\end{array}$ & $\begin{array}{c}-0.003 * \\
(0.002)\end{array}$ & $\begin{array}{c}0.008 \\
(0.016)\end{array}$ & $\begin{array}{r}-0.0002 \\
(0.001)\end{array}$ & $\begin{array}{r}-0.0002 \\
(0.001)\end{array}$ & $\begin{array}{c}-0.0002 \\
(0.001)\end{array}$ \\
\hline Firm Age & $\begin{array}{l}0.0002 \\
(0.114)\end{array}$ & $\begin{array}{c}0.005 \\
(0.006)\end{array}$ & $\begin{array}{l}-0.004 \\
(0.113)\end{array}$ & $\begin{array}{l}-0.018 \\
(0.031)\end{array}$ & $\begin{array}{l}-0.015 \\
(0.018)\end{array}$ & $\begin{array}{c}0.057 \\
(0.049)\end{array}$ \\
\hline $\begin{array}{l}\text { Ind-adj. } \\
\text { ROA }\end{array}$ & $\begin{array}{c}1.418 * * * \\
(0.291)\end{array}$ & $\begin{array}{c}0.487 * * * \\
(0.072)\end{array}$ & $\begin{array}{c}0.930 * * * \\
(0.255)\end{array}$ & $\begin{array}{c}0.504 * * * \\
(0.077)\end{array}$ & $\begin{array}{c}0.227 * * * \\
(0.045)\end{array}$ & $\begin{array}{c}-0.201 * * * \\
(0.046)\end{array}$ \\
\hline $\begin{array}{l}\text { Ind-adj. } \\
\text { Return }\end{array}$ & $\begin{array}{c}0.060 \\
(0.042)\end{array}$ & $\begin{array}{c}0.037 * * * \\
(0.009)\end{array}$ & $\begin{array}{c}0.023 \\
(0.038)\end{array}$ & $\begin{array}{c}0.036^{* * *} \\
(0.009)\end{array}$ & $\begin{array}{c}0.031 * * * \\
(0.006)\end{array}$ & $\begin{array}{l}-0.006 \\
(0.006)\end{array}$ \\
\hline MB & $\begin{array}{c}0.011 * * \\
(0.005)\end{array}$ & $\begin{array}{c}0.007 * * * \\
(0.002)\end{array}$ & $\begin{array}{c}0.004 \\
(0.004)\end{array}$ & $\begin{array}{c}0.012 * * * \\
(0.002)\end{array}$ & $\begin{array}{c}0.003 * * * \\
(0.001)\end{array}$ & $\begin{array}{c}0.001 \\
(0.001)\end{array}$ \\
\hline Leverage & $\begin{array}{c}-0.892 * * * \\
(0.193)\end{array}$ & $\begin{array}{c}-0.083 \\
(0.051)\end{array}$ & $\begin{array}{c}-0.810 * * * \\
(0.182)\end{array}$ & $\begin{array}{c}-0.302 * * * \\
(0.052)\end{array}$ & $\begin{array}{c}-0.129 * * * \\
(0.036)\end{array}$ & $\begin{array}{c}0.069 \\
(0.043)\end{array}$ \\
\hline Div. Payer & $\begin{array}{c}0.117 * * \\
(0.048)\end{array}$ & $\begin{array}{c}0.014 \\
(0.010)\end{array}$ & $\begin{array}{c}0.102 * * \\
(0.046)\end{array}$ & $\begin{array}{c}0.050 * * * \\
(0.017)\end{array}$ & $\begin{array}{l}0.021^{*} \\
(0.012)\end{array}$ & $\begin{array}{l}-0.018 \\
(0.020)\end{array}$ \\
\hline $\log$ (Assets) & $\begin{array}{c}-0.601 * * * \\
(0.072)\end{array}$ & $\begin{array}{c}-0.071 * * * \\
(0.014)\end{array}$ & $\begin{array}{c}-0.531^{* * *} \\
(0.066)\end{array}$ & $\begin{array}{c}-0.339 * * * \\
(0.023)\end{array}$ & $\begin{array}{c}-0.155^{* * *} \\
(0.012)\end{array}$ & $\begin{array}{c}0.035 * * * \\
(0.013)\end{array}$ \\
\hline Constant & $\begin{array}{c}4.828 \\
(3.666)\end{array}$ & $\begin{array}{c}0.767 * * * \\
(0.253)\end{array}$ & $\begin{array}{c}4.061 \\
(3.615)\end{array}$ & $\begin{array}{c}3.317 * * * \\
(0.953)\end{array}$ & $\begin{array}{c}1.774 * * * \\
(0.561)\end{array}$ & $\begin{array}{l}-1.706 \\
(1.485)\end{array}$ \\
\hline $\begin{array}{l}\text { Firm and } \\
\text { Year F.E. }\end{array}$ & $\mathrm{X}$ & $\mathrm{x}$ & $\mathrm{x}$ & $\mathrm{x}$ & $\mathrm{X}$ & $\mathrm{x}$ \\
\hline Obs. & 15,261 & 15,261 & 15,261 & 15,442 & 15,233 & 15,442 \\
\hline Adj. R-sqr. & 0.265 & 0.457 & 0.202 & 0.235 & 0.179 & 0.335 \\
\hline
\end{tabular}




\section{Panel C: Instrumental Variables Estimates of the Effect of CEO Power on Investment}

This table reports the results with the instrumented "\% of New Directors", using the cumulative number of retired directors (72 or beyond when service ends) during the incumbent CEO's tenure until the current fiscal year, scaled by the current board size. Control variables except for Firm Age are lagged. Firm and Year Fixed effects are included in all models. The definitions of all variables are in Appendix A. The Huber-White-Sandwich robust standard errors are clustered by firm and reported in parenthesis. ${ }^{* * *}, * *$ and $*$ indicate significance at the $1 \%, 5 \%$ and $10 \%$ levels respectively. The F-statistics for the first-stage and the Anderson-Rubin Wald tests are reported at the bottom of the table.

\begin{tabular}{|c|c|c|c|c|c|c|}
\hline & $\begin{array}{l}\text { First-Stage } \\
\% \text { of New } \\
\text { Directors } \\
\end{array}$ & $\begin{array}{c}(1) \\
\text { Investment } \\
\text { Rate } \\
\end{array}$ & $\begin{array}{c}(2) \\
\text { CapEx } \\
\text { Rate } \\
\end{array}$ & $\begin{array}{c}\text { (3) } \\
\text { Acquisition } \\
\text { Rate } \\
\end{array}$ & $\begin{array}{c}\text { (4) } \\
\text { Asset } \\
\text { Growth Rate }\end{array}$ & $\begin{array}{l}\text { (5) } \\
\text { Employment } \\
\text { Growth Rate }\end{array}$ \\
\hline $\begin{array}{l}\text { Retired } \\
\text { Directors }\end{array}$ & $\begin{array}{c}0.237 * * * \\
(0.029)\end{array}$ & & & & & \\
\hline $\begin{array}{l}\% \text { of New } \\
\text { Directors }\end{array}$ & & $\begin{array}{l}0.555^{*} \\
(0.314)\end{array}$ & $\begin{array}{c}0.028 * * \\
(0.014)\end{array}$ & $\begin{array}{l}0.527^{*} \\
(0.291)\end{array}$ & $\begin{array}{c}0.323 * * * \\
(0.102)\end{array}$ & $\begin{array}{c}0.216^{* * *} \\
(0.067)\end{array}$ \\
\hline CEO Age & $\begin{array}{c}0.021 * * * \\
(0.001)\end{array}$ & $\begin{array}{c}-0.020 * * \\
(0.008)\end{array}$ & $\begin{array}{c}-0.001^{*} \\
(0.000)\end{array}$ & $\begin{array}{c}-0.018 * * \\
(0.007)\end{array}$ & $\begin{array}{c}-0.006^{* *} \\
(0.002)\end{array}$ & $\begin{array}{c}-0.004 * * * \\
(0.002)\end{array}$ \\
\hline Firm Age & $\begin{array}{l}-0.079 \\
(0.056)\end{array}$ & $\begin{array}{c}0.041 \\
(0.091)\end{array}$ & $\begin{array}{l}-0.002 \\
(0.003)\end{array}$ & $\begin{array}{c}0.040 \\
(0.090)\end{array}$ & $\begin{array}{l}-0.002 \\
(0.027)\end{array}$ & $\begin{array}{l}-0.003 \\
(0.016)\end{array}$ \\
\hline $\begin{array}{l}\text { Ind-adj. } \\
\text { ROA }\end{array}$ & $\begin{array}{c}0.140 * * * \\
(0.040)\end{array}$ & $\begin{array}{c}1.234 * * * \\
(0.215)\end{array}$ & $\begin{array}{c}0.078 * * * \\
(0.008)\end{array}$ & $\begin{array}{c}0.721^{* * * *} \\
(0.192)\end{array}$ & $\begin{array}{c}0.470 * * * \\
(0.078)\end{array}$ & $\begin{array}{c}0.202 * * * \\
(0.047)\end{array}$ \\
\hline $\begin{array}{l}\text { Ind-adj. } \\
\text { Return }\end{array}$ & $\begin{array}{c}0.006 \\
(0.004)\end{array}$ & $\begin{array}{c}0.075 * * \\
(0.034)\end{array}$ & $\begin{array}{c}0.004 * * * \\
(0.001)\end{array}$ & $\begin{array}{c}0.038 \\
(0.031)\end{array}$ & $\begin{array}{c}0.035^{* * *} \\
(0.008)\end{array}$ & $\begin{array}{c}0.030 * * * \\
(0.006)\end{array}$ \\
\hline MB & $\begin{array}{c}0.000 \\
(0.001)\end{array}$ & $\begin{array}{c}0.014 * * * \\
(0.005)\end{array}$ & $\begin{array}{c}0.001 * * * \\
(0.000)\end{array}$ & $\begin{array}{l}0.007^{*} \\
(0.004)\end{array}$ & $\begin{array}{c}0.011 * * * \\
(0.002)\end{array}$ & $\begin{array}{c}0.003 * * * \\
(0.001)\end{array}$ \\
\hline Leverage & $\begin{array}{c}0.011 \\
(0.037)\end{array}$ & $\begin{array}{c}-0.689 * * * \\
(0.136)\end{array}$ & $\begin{array}{c}-0.051 * * * \\
(0.006)\end{array}$ & $\begin{array}{c}-0.598 * * * \\
(0.127)\end{array}$ & $\begin{array}{c}-0.306 * * * \\
(0.051)\end{array}$ & $\begin{array}{c}-0.132 * * * \\
(0.036)\end{array}$ \\
\hline Div. Payer & $\begin{array}{c}-0.043 * * \\
(0.018)\end{array}$ & $\begin{array}{c}0.126^{* * *} \\
(0.047)\end{array}$ & $\begin{array}{l}-0.002 \\
(0.002)\end{array}$ & $\begin{array}{c}0.117 * * * \\
(0.044)\end{array}$ & $\begin{array}{c}0.059 * * * \\
(0.019)\end{array}$ & $\begin{array}{c}0.028 * * \\
(0.014)\end{array}$ \\
\hline $\log$ (Assets) & $\begin{array}{c}-0.027 * * \\
(0.011)\end{array}$ & $\begin{array}{c}-0.483 * * * \\
(0.047)\end{array}$ & $\begin{array}{c}-0.016^{* * *} \\
(0.002)\end{array}$ & $\begin{array}{c}-0.413 * * * \\
(0.044)\end{array}$ & $\begin{array}{c}-0.334 * * * \\
(0.022)\end{array}$ & $\begin{array}{c}-0.152 * * * \\
(0.011)\end{array}$ \\
\hline $\begin{array}{l}\text { Firm and } \\
\text { Year F.E. }\end{array}$ & $(0.011)$ & (- & ()$^{2}-1$ & (- & ( & $\mathrm{x}$ \\
\hline Obs. & 15,033 & 15,033 & 15,033 & 15,033 & 15,206 & 14,997 \\
\hline $\begin{array}{l}\text { First-Stage } \\
\text { F-Statistics } \\
\text { Anderson- } \\
\text { Rubin } \\
\text { Wald test }\end{array}$ & $74.45 * * *$ & $4.30 * *$ & $3.35 *$ & 10 & $3 * * *$ & $11.07 * * *$ \\
\hline
\end{tabular}




\section{Panel D: Market Reaction to Acquisitions and CEO Power}

This table reports the effect of CEO power on the three-day cumulative market-adjusted return around acquisition announcements. The market return is constructed using the value-weighted market portfolio. Models (1) and (2) report the results for the full sample. Models (3) and (4) report the results for CEOs with non-forced departures. Model (5) reports the $2^{\text {nd }}$ stage results of the instrumental variable approach, in which the measure for CEO power $(\%$ of New Director) is instrumented using the cumulative number of retired directors (72 or above when service ends) during the incumbent CEO's tenure until the current fiscal year, scaled by the current board size. Control variables include dealspecific variables (deal size, \% of stock as the source of the fund, and an indicator variable for public target) and firmspecific variables (cash ratio, M/B, firm size) which are lagged. Year Fixed effects are included in all models. The definitions of all variables are in Appendix A. The Huber-White-Sandwich robust standard errors are clustered by firm and reported in parenthesis. ${ }^{* * *},{ }^{* *}$ and $*$ indicate significance at the $1 \%, 5 \%$ and $10 \%$ levels respectively.

\begin{tabular}{|c|c|c|c|c|c|}
\hline & \multicolumn{5}{|c|}{ CAR $[-1,1]$ around Acquisition Announcements } \\
\hline & \multicolumn{2}{|c|}{ Full Sample } & \multicolumn{2}{|c|}{ Non-forced Departures } & \multirow{2}{*}{$\begin{array}{c}\text { IV } 2^{\text {nd }} \text { Stage } \\
(5) \\
\end{array}$} \\
\hline & (1) & (2) & (3) & (4) & \\
\hline \multirow[t]{2}{*}{ Years $[0,2]$} & $0.002 * *$ & & $0.003 * *$ & & \\
\hline & $(0.001)$ & & $(0.001)$ & & \\
\hline \multirow[t]{2}{*}{$\%$ of New Directors } & & $-0.009 * *$ & & $-0.009 * *$ & $-0.043^{*}$ \\
\hline & & $(0.004)$ & & $(0.004)$ & $(0.023)$ \\
\hline \multirow[t]{2}{*}{ Public Target } & $-0.008 * * *$ & $-0.004 * *$ & $-0.007 * * *$ & -0.003 & $-0.004 * *$ \\
\hline & $(0.001)$ & $(0.002)$ & $(0.001)$ & $(0.002)$ & $(0.002)$ \\
\hline \multirow[t]{2}{*}{$\log ($ Deal value $)$} & $0.001 * * *$ & 0.0002 & $0.001 * * *$ & 0.0001 & $0.001 *$ \\
\hline & $(0.0003)$ & $(0.0005)$ & $(0.0003)$ & $(0.0005)$ & $(0.0003)$ \\
\hline \multirow[t]{2}{*}{$\%$ of stock } & $-0.008 * * *$ & $-0.015 * * *$ & $-0.008 * * *$ & $-0.014 * * *$ & -0.006 \\
\hline & $(0.002)$ & $(0.004)$ & $(0.002)$ & $(0.004)$ & $(0.005)$ \\
\hline \multirow[t]{2}{*}{ Cash Ratio } & -0.006 & 0.006 & -0.005 & 0.016 & 0.003 \\
\hline & $(0.008)$ & $(0.014)$ & (0.009) & $(0.015)$ & $(0.013)$ \\
\hline \multirow[t]{2}{*}{$\mathrm{MB}$} & 0.0003 & 0.0002 & 0.0003 & 0.0002 & 0.0003 \\
\hline & $(0.0002)$ & $(0.0003)$ & $(0.0002)$ & $(0.0003)$ & $(0.0002)$ \\
\hline \multirow[t]{2}{*}{$\log$ (Assets) } & $-0.004 * * *$ & $-0.008 * * *$ & $-0.004 * * *$ & $-0.007 * *$ & $-0.004 * * *$ \\
\hline & $(0.0004)$ & $(0.003)$ & $(0.0005)$ & $(0.003)$ & $(0.001)$ \\
\hline \multirow[t]{2}{*}{ Constant } & 0.007 & $0.080 * * *$ & 0.017 & $0.072 * * *$ & $0.119 * *$ \\
\hline & $(0.013)$ & $(0.023)$ & $(0.012)$ & $(0.025)$ & $(0.055)$ \\
\hline Year F.E. & $\mathrm{x}$ & $\mathrm{x}$ & $\mathrm{x}$ & $\mathrm{x}$ & $\mathrm{x}$ \\
\hline Obs. & 14,846 & 8,533 & 13,933 & 7,813 & 8,533 \\
\hline Adj. R-sqr. & 0.029 & 0.044 & 0.031 & 0.051 & \\
\hline
\end{tabular}




\section{Appendix A: Variable Definitions}

\begin{tabular}{|c|c|}
\hline Tenure (in years) & $\begin{array}{l}\text { CEO's tenure is the number of years starting from the year when he } \\
\text { took office (based on the variable becameceo in Execucomp), that is, } \\
\text { (year-became CEO year). }\end{array}$ \\
\hline Tenure (in months) & $\begin{array}{l}\text { CEO's tenure is the number of months starting from the month when } \\
\text { he took office (based on the variable becameceo in Execucomp) }\end{array}$ \\
\hline Years $[0,2]$ & $\begin{array}{l}\text { An indicator variable that equals } 1 \text { if CEO is his tenure between year } 0 \\
\text { (the year he became CEO) and year } 2,0 \text { otherwise. }\end{array}$ \\
\hline Months $[0,24]$ & $\begin{array}{l}\text { An indicator variable that equals } 1 \text { if } \mathrm{CEO} \text { is his tenure between month } \\
0 \text { and month } 24,0 \text { otherwise. }\end{array}$ \\
\hline CEO Total Time in Office & $\begin{array}{l}\text { CEO's total time in office is constructed as the maximal time in office } \\
\text { in our sample, that is, } \max (\text { year-became CEO year) }\end{array}$ \\
\hline CEO Age & The age of the CEO in the fiscal year. \\
\hline Long-term CEO & CEOs with total time in office greater or equal to six. \\
\hline Outsider Succession & $\begin{array}{l}\text { An indicator that equals } 1 \text { if the CEO is hired from outside of the } \\
\text { company (i.e, with the firm for less than three years when became } \\
\text { CEO) }\end{array}$ \\
\hline Exogenous Turnover & $\begin{array}{l}\text { Exogenous turnovers include cases where a) news searches revealed } \\
\text { that the CEO departure was related to a health condition or death (from } \\
\text { Fee et al. 2013), b) turnover reason provided in Execucomp is } \\
\text { "deceased", c) departing CEOs older than } 65 \text { years. }\end{array}$ \\
\hline Forced Turnover & $\begin{array}{l}\text { Forced turnovers include the "overtly forced" group from Fee et al. } \\
\text { (2013) with cases for which news searches indicated that the CEO was } \\
\text { forced to leave or left under pressure. }\end{array}$ \\
\hline$I_{\{\text {asset sales }>0\}}$ & $\begin{array}{l}\text { An indicator function that equals } 1 \text { of the firm engages as the target in } \\
\text { completed asset sales in the fiscal year. Asset Sales include deals } \\
\text { covered in the SDC Platinum database with deal forms of either } \\
\text { "Acquisitions of Assets" or "Acquisitions of certain Assets". }\end{array}$ \\
\hline$I_{\{\text {discontinued operations }>0\}}$ & $\begin{array}{l}\text { An indicator function that equals } 1 \text { of the firm reports discontinued } \\
\text { operations (inflow/outflow of funds due to discontinuation of } \\
\text { operations (item "DO" in Compustat) in the fiscal year. }\end{array}$ \\
\hline$I_{\{\text {asset sales }>0 \text { or discontinued operations }>0\}}$ & $\begin{array}{l}\text { An indicator function that equals } 1 \text { of the firm either had asset sales or } \\
\text { discontinued operations in the fiscal year. }\end{array}$ \\
\hline$I_{\{\text {downsizing announcement(s) in the month\} }}$ & $\begin{array}{l}\text { An indicator variable that equals to one if the company makes } \\
\text { downsizing announcement (Events } 1,21 \text { in Capital IQ) in a month }\end{array}$ \\
\hline$I_{\{\text {segment termination }\}}$ & $\begin{array}{l}\text { An indicator variable that equals to one if the segment is divested or } \\
\text { discontinued in the fiscal year, } 0 \text { otherwise. }\end{array}$ \\
\hline Disinvestment Rate & $\begin{array}{l}\text { [Value of asset sales if there is asset sales + Value of discontinued } \\
\text { operations if there is discontinuation of operations]/lagged PPE (net). } \\
\text { Value of asset sales is the transaction value from SDC. Value of } \\
\text { discontinued operations is the maximum value of (sale of PPE, assets } \\
\text { of discontinued operations, income from discontinued operations) } \\
\text { based on Compustat information. Sale of PPE is the item "SPPE". } \\
\text { Assets of discontinued operations are the sum of current assets (item } \\
\text { "ACDO") and long-term assets (item "ALDO"). Income from } \\
\text { discontinued operations id based on the item"DO". }\end{array}$ \\
\hline Restructuring Rate & $\begin{array}{l}\text { Absolute value of the pre-tax restructuring cost (item "RCP" in } \\
\text { Compustat)/lagged PPE (net) }\end{array}$ \\
\hline$I_{\{\text {expansion announcement(s) in the month\} }}$ & An indicator variable that equals to one if the company makes \\
\hline
\end{tabular}




\begin{tabular}{|c|c|}
\hline & expansion announcements (Events 3 or 31 in Capital IQ) in a month \\
\hline$I_{\{\text {new segment\} }}$ & $\begin{array}{l}\text { An indicator variable that equals } 1 \text { if the segment is newly established } \\
\text { in the fiscal year, } 0 \text { otherwise. }\end{array}$ \\
\hline Acquisition Rate & $\begin{array}{l}\text { Value of acquisitions/lagged PPE (net). Acquisitions include } \\
\text { completed deals covered in SDC with the deal form of "Acquisitions } \\
\text { of Assets", "Acquisitions of certain Assets", "Acq. Maj. Int.", "Acq. } \\
\text { Part. Int.", "Acq. Rem. Int.", "Acquisition" or "Merger" (as the } \\
\text { acquirer"). }\end{array}$ \\
\hline Capx Rate & $\begin{array}{l}\text { Capital expenditure/lagged PPE (net), with missing or negative Capx } \\
\text { set to } 0 \text {. }\end{array}$ \\
\hline Investment Rate & (Value of acquisitions + Capital expenditure)/lagged PPE (net) \\
\hline Asset Growth Rate & $\begin{array}{l}\text { Total assets in the fiscal year - total assets last fiscal year/total assets } \\
\text { last fiscal year }\end{array}$ \\
\hline Employment Growth Rate & $\begin{array}{l}\text { Total employment in the fiscal year - total employment last fiscal } \\
\text { year/total employment last fiscal year }\end{array}$ \\
\hline Firm Age & $\begin{array}{l}\text { Age of the firm since IPO, using the first day appear in CRSP (or the } \\
\text { IPO date in Compustat if missing) }\end{array}$ \\
\hline Leverage & (Long-term debt + debt in current liabilities)/total assets \\
\hline $\mathrm{M} / \mathrm{B}$ & $\begin{array}{l}\text { Market value of equity (closing price at the fiscal year end times } \\
\text { shares outstanding) divided by book value of equity }\end{array}$ \\
\hline Div. Payer & $\begin{array}{l}\text { An indicator variable that equals } 1 \text { if the firm pays out dividend to } \\
\text { common stock holders in a year }\end{array}$ \\
\hline Log(Assets) & Logarithm of the total book assets \\
\hline Ind-adj. Return & Industry (Fama-French 49)-adjusted return \\
\hline Ind-adj. ROA & $\begin{array}{l}\text { Industry (Fama-French 49)-adjusted ROA. ROA is defined as the } \\
\text { earnings before interest, tax, and depreciation scaled by the beginning } \\
\text { of fiscal year total book assets. }\end{array}$ \\
\hline Cash Ratio & Cash divided by total assets \\
\hline Recession & $\begin{array}{l}\text { An indicator variable that equals } 1 \text { if the fiscal year falls into one of the } \\
\text { recession years: 1980,1981,1982,1990,1991,2001,2008,2009, } \\
2010 \text {. }\end{array}$ \\
\hline Original CEO Replaced & $\begin{array}{l}\text { An indicator variable that equal } 1 \text { if the reigning CEO is different from } \\
\text { the original CEO who established the segment }\end{array}$ \\
\hline Underperforming Segment & $\begin{array}{l}\text { An indicator variable that equals } 1 \text { if the lagged segment performance } \\
\text { was at the bottom } 10 \% \text { of the sample distribution (segment operating } \\
\text { profits/loss scaled by sales less than }-7.4 \% \text { ) }\end{array}$ \\
\hline \# of Segments & The number of segments (defined by segment id) in a firm-year \\
\hline Segment Age & Time (in years) since the segment was established \\
\hline Old CEO Stay As Chairman & $\begin{array}{l}\text { An indicator that equals if the old CEO stays as the Chairman of the } \\
\text { Board during the first year of the new CEO's tenure }\end{array}$ \\
\hline$\%$ of Old Mgmt. On Board & $\begin{array}{l}\text { the } \% \text { of the old management (top- } 4 \text { highest paid executives besides } \\
\text { CEO) that serves as directors on the board during the first year of the } \\
\text { new CEO's tenure }\end{array}$ \\
\hline Staggered Board & $\begin{array}{l}\text { An indicator variable that equals to } 1 \text { if the board of directors is } \\
\text { divided, for the purpose of election, into separate classes. In most } \\
\text { instances there are three classes, with the directors in each class } \\
\text { serving overlapping three-year terms. With a classified board, also } \\
\text { known as a staggered board, the shareholders' ability to affect the } \\
\text { makeup of the board is limited because it would take at least two } \\
\text { elections to replace a majority of the board. This variable is }\end{array}$ \\
\hline
\end{tabular}




\begin{tabular}{|c|c|}
\hline & constructed using RiskMetrics' governance database. \\
\hline$\%$ of New Directors & $\begin{array}{l}\text { The percentage of directors appointed during the incumbent CEO's in } \\
\text { the board, using RiskMetrics' director database. }\end{array}$ \\
\hline Retired Directors & $\begin{array}{l}\text { The cumulative number of retired directors ( } 72 \text { or above when service } \\
\text { ends) during the incumbent CEO's tenure up until the current fiscal } \\
\text { year, scaled by the current board size, using RiskMetrics' director } \\
\text { database. }\end{array}$ \\
\hline CEO Ownership & $\begin{array}{l}\text { CEO's equity ownership which is direct stock ownership, using } \\
\text { Execucomp data. }\end{array}$ \\
\hline CEO PPS & $\begin{array}{l}\text { The sum of equity ownership and the incentives from stock options, } \\
\text { following Aggarwal and Samwick (2003). For each option grant, the } \\
\text { incentive is calculated as the number of underlying equity shares } \\
\text { multiplied by the option delta }\end{array}$ \\
\hline CEO being Chairman & $\begin{array}{l}\text { An indicator variable that takes the value of one if the CEO is also } \\
\text { Chairman of the Board, and zero otherwise using RiskMetrics' director } \\
\text { database. }\end{array}$ \\
\hline $\begin{array}{l}\text { CAR }[-1,1] \text { around Acquisition } \\
\text { Announcement }\end{array}$ & $\begin{array}{l}\text { 3-day cumulative market-adjusted return around acquisition } \\
\text { announcements. The market-adj. Return is calculated as daily stock } \\
\text { return minus the (value-weighted) market return on the same day. }\end{array}$ \\
\hline Public Target & $\begin{array}{l}\text { An indicator variable that equals one if the target is a public target, } \\
\text { using SDC Platinum data. }\end{array}$ \\
\hline$\%$ of stock & $\begin{array}{l}\text { Percentage of stock used to fund an acquisition, using "ofstock" from } \\
\text { SDC Platinum if non-missing, and replaced with 1-"ofcash" if the } \\
\text { previous variable is unavailable, and then replaced with } 0 \text { if SDC } \\
\text { indicated that the source of fund is neither from common stocks nor } \\
\text { from preferred stocks. }\end{array}$ \\
\hline Log(Deal Size) & $\begin{array}{l}\text { Logarithm of the value of transaction (in Millions, from SDC } \\
\text { Platinum) }\end{array}$ \\
\hline
\end{tabular}




\section{Appendix B: Estimates of the Effect of other Factors on Investment Compared to the CEO}

\section{Investment Cycle}

Business cycles: Firm level and aggregate corporate investment rates tend to vary substantially between expansions and recessions. In Appendix Table B1, we compare the magnitude of the business cycle effect to the CEO cycle effect. To do so, we define Recession as an indicator variable that equals one for years 1980-1982, 1990-1991, 2001, 2008-2010 and include this variable into the specification predicting changes in disinvestment, investment, and firm growth.

Columns (1) and (2) of Appendix Table B show that disinvestment is actually less likely to occur in recession years than in expansion years, and thus the business cycle effect on disinvestment intensity is very different from the CEO cycle effect. Columns (3)-(5) show that the corporate investment rate is much lower in recession years than in non-recession years. The CEO cycle effect on investment is about half the magnitude of the effect of the business cycle: the total investment rate is 13 percentage points lower in recessions than in other years, and it is about 6 percentage points lower in early CEO tenure years than in later years $(42 \%$ of the recession effect). Columns (6)-(7) show that the effects of CEO tenure and the business cycle on asset growth and employment growth are comparable in magnitude. The CEO cycle effect on corporate investment is non-trivial compared to the effect of the business cycle.

Political uncertainty: Julio and Yook (2012) estimate the extent to which corporate investment varies over the political election cycle. These authors find that the corporate investment rate (capital expenditures scaled by the beginning-of-year book assets) is on average 0.4 percentage point lower in national election years than in non-election years, or a $5 \%$ reduction relative to the sample median rate $(=5.1 \%)$. If we use the same definition of investment rate as in their study, then our estimates indicate that the investment rate is 1.0 percentage point lower in early CEO tenure years than in later years, an almost $20 \%$ reduction relative to the sample median of $5.2 \%$. This estimate is more than double the election cycle effect documented by Julio and Yook (2012).

Financial constraints: If firms face financial constraints, meaning that their cost of finance exceeds the appropriate risk-adjusted rate of return, then firms' investment is likely to be reduced. Using a 
text-based approach to measure the existence of financial constraints, Ball, Hoberg and Maksimovic (2013) estimate that during the 2008-2009 Financial Crisis, a one standard-deviation increase in financial constraint is associated with a decrease in the annual corporate investment rate (CAPX scaled by sales) in the range of $0 \%$ to $0.8 \%$, depending on the measure of financial constraint they use. In other years, the estimated effect of financial constraints on investment is smaller than during the Financial Crisis. If we convert our estimates to comparable units, our estimates imply that the difference in investment rate between early and late years of the $\mathrm{CEO}$ cycle is about $0.4 \%$, in the range that Ball, Hoberg and Maksimovic find for the Financial Crisis and larger than what they find in other periods. 


\section{Table B: The Effect on Investment and Disinvestment: Recessions and CEO Turnover}

This table compares the effect of a recession dummy with the time dummy capturing the effect of the CEO cycle on various (dis)investment variables. A constant term is included in all models but omitted for brevity. Other control variables except for Firm Age are lagged. Firm Fixed effects are included in all models. The definitions of all variables are in Appendix A. The Huber-White-Sandwich robust standard errors are clustered by firm and reported in parenthesis. $* * *, * *$ and $*$ indicate significance at the $1 \%, 5 \%$ and $10 \%$ levels respectively.

\begin{tabular}{|c|c|c|c|c|c|c|c|}
\hline & (1) & (2) & (3) & (4) & (5) & (6) & (7) \\
\hline & $\begin{array}{c}I_{\{\text {asset sales }>0 \text { or }} \\
\text { discontinued } \\
\text { operations }>0\} \\
\end{array}$ & $\begin{array}{c}\text { Disinvestment } \\
\text { Rate }\end{array}$ & $\begin{array}{c}\text { Acquisition } \\
\text { Rate }\end{array}$ & Capx Rate & Investment Rate & $\begin{array}{c}\text { Asset Growth } \\
\text { Rate }\end{array}$ & $\begin{array}{l}\text { Employment } \\
\text { Growth Rate }\end{array}$ \\
\hline \multirow[t]{2}{*}{ Recession } & $-0.032 * * *$ & $-0.010 * * *$ & $-0.103 * * *$ & $-0.028 * * *$ & $-0.132 * * *$ & $-0.060 * * *$ & $-0.044 * * *$ \\
\hline & $(0.005)$ & $(0.002)$ & $(0.015)$ & $(0.004)$ & $(0.016)$ & $(0.005)$ & $(0.004)$ \\
\hline \multirow[t]{2}{*}{ Years $[0,2]$} & $0.039 * * *$ & $0.009 * * *$ & $-0.032 * *$ & $-0.023 * * *$ & $-0.055 * * *$ & $-0.032 * * *$ & $-0.024 * * *$ \\
\hline & $(0.006)$ & $(0.003)$ & $(0.015)$ & $(0.005)$ & $(0.016)$ & $(0.006)$ & $(0.004)$ \\
\hline \multirow[t]{2}{*}{ CEO Age } & $-0.002 * *$ & -0.000 & $-0.003 * *$ & $-0.002 * * *$ & $-0.005 * * *$ & -0.000 & $-0.001 * * *$ \\
\hline & $(0.001)$ & $(0.000)$ & $(0.002)$ & $(0.000)$ & $(0.002)$ & $(0.001)$ & $(0.000)$ \\
\hline \multirow[t]{2}{*}{ Firm Age } & $0.013 * * *$ & $0.003 * * *$ & $0.013 * * *$ & $0.002 * * *$ & $0.015 * * *$ & $0.011 * * *$ & $0.004 * * *$ \\
\hline & $(0.001)$ & $(0.000)$ & $(0.002)$ & $(0.001)$ & $(0.002)$ & $(0.001)$ & $(0.001)$ \\
\hline \multirow[t]{2}{*}{ Ind-adj. ROA } & $-0.170 * * *$ & $-0.041 * * *$ & $0.730 * * *$ & $0.296 * * *$ & $1.026 * * *$ & $0.268 * * *$ & $0.217 * * *$ \\
\hline & $(0.023)$ & $(0.012)$ & $(0.104)$ & $(0.059)$ & $(0.133)$ & $(0.065)$ & $(0.032)$ \\
\hline \multirow[t]{2}{*}{ Ind-adj. Return } & $-0.007 * *$ & -0.003 & $0.049 * * *$ & $0.044 * * *$ & $0.092 * * *$ & $0.055 * * *$ & $0.027 * * *$ \\
\hline & $(0.003)$ & $(0.002)$ & $(0.015)$ & $(0.005)$ & $(0.017)$ & $(0.007)$ & $(0.004)$ \\
\hline \multirow[t]{2}{*}{ MB } & -0.001 & 0.000 & $0.010 * * *$ & $0.008 * * *$ & $0.019 * * *$ & $0.014 * * *$ & $0.004 * * *$ \\
\hline & $(0.001)$ & $(0.000)$ & $(0.003)$ & $(0.001)$ & $(0.003)$ & $(0.002)$ & $(0.001)$ \\
\hline \multirow[t]{2}{*}{ Leverage } & $0.069 * * *$ & $0.040 * * *$ & $-0.389 * * *$ & $-0.211 * * *$ & $-0.601 * * *$ & $-0.260 * * *$ & $-0.148 * * *$ \\
\hline & $(0.021)$ & $(0.011)$ & $(0.063)$ & $(0.026)$ & $(0.072)$ & $(0.031)$ & $(0.022)$ \\
\hline \multirow[t]{2}{*}{ Div. Payer } & $-0.029 * *$ & -0.004 & $0.093 * * *$ & $0.013 * *$ & $0.106^{* * *}$ & $0.050 * * *$ & $0.024 * *$ \\
\hline & $(0.012)$ & $(0.005)$ & $(0.029)$ & $(0.007)$ & $(0.030)$ & $(0.013)$ & $(0.009)$ \\
\hline \multirow[t]{2}{*}{$\log$ (Assets) } & $0.013 * *$ & -0.005 & $-0.153 * * *$ & $-0.077 * * *$ & $-0.230 * * *$ & $-0.205 * * *$ & $-0.103 * * *$ \\
\hline & $(0.006)$ & $(0.004)$ & $(0.021)$ & $(0.007)$ & $(0.024)$ & $(0.010)$ & $(0.006)$ \\
\hline Obs. & 33,186 & 32,722 & 32,722 & 32,722 & 32,722 & 33,186 & 32,370 \\
\hline Adj. R-sqr. & 0.267 & 0.092 & 0.186 & 0.333 & 0.239 & 0.190 & 0.168 \\
\hline
\end{tabular}




\section{Appendix C: Industry Productivity Shocks and CEO Investment Cycles}

In Appendix Table C, we examine the impact of industry productivity shocks on the magnitudes of the CEO investment cycles. We use a variety of measures to capture the changes in industry conditions as of the CEO turnover year. We examine changes in the industry median ROA, sales growth rate, employment growth rate, and in the industry total factor productivity. The industry total factor productivity is constructed following Jorgenson and Griliches (1976). ${ }^{18}$ For each industry shock measure, we also capture the changes over different horizons: year-to-year changes and three-year cumulative changes. Then we classify the nature of the shock by dividing turnover-year industry conditions into negative, neutral, or positive shocks based on the tercile distribution (bottom, middle, top) of each industry shock measure. This procedure generates 24 categories of industry conditions at the time of CEO turnover: 4 (performance measures) $* 2$ (horizons) $* 3$ (types) $=24$. Finally, within each of the 24 categories, we estimate the magnitudes of the CEO disinvestment cycle (Panel A) and the investment cycle (Panel B) using the baseline regressions in Tables 2 and 3. We report the coefficient estimate for the "Years [0,2]" indicator variable and its standard error under each category.

The results in Table $\mathrm{C}$ show that both the CEO disinvestment cycle and the investment cycle exist regardless of the industry condition in which the CEO takes office. Moreover, even the magnitudes of the cycles are similar across industry conditions. These results suggest that the CEO cycle does not occur because of productivity shocks coinciding with the CEO changes.

\footnotetext{
${ }^{18}$ Dale Jorgenson provides data on industry input and output for 35 sectors (see ind.comm.detail.doc) for 1960 2005. In this data set, he provides the price and quantity of industry output, as well as the price and quantity of inputs, including capital, labor, (intermediate use of) energy, materials, agriculture, metallic materials, non-metallic materials, services materials, textile-apparel, wood paper, other services, Fab-other metals, machinery materials, and equipment.
} 


\section{Table C: Industry Shocks and CEO Investment Cycle}

This table reports the coefficient estimates on the CEO cycle indicator Years $[0,2]$ in the disinvestment and investment regressions, for subsamples based on various definitions of industry shocks. For example, "Shock based on Industry ROA, 1 (3) year" measures the year-to-year change (the 3-year cumulative change) in the industry median of firm-year level ROA. Shocks based on Sales Growth and Employment Growth are constructed using changes in the industry medians sales growth and employment growth. Shocks based on Total Factor Productivity measures the changes (rate of growth) in total factor productivity, following Jorgenson and Griliches (1967). We then define negative (neutral, positive) shock to be the bottom (middle, top) tercile of the sample distribution for each industry shock measure. The Huber-White robust standard errors are clustered by firm and reported in parenthesis. ***, ** and * indicate significance at the $1 \%, 5 \%$ and $10 \%$ levels respectively.

Panel A: Coefficients of Regressing Disinvestment Probability on the CEO Cycle Indicator

\begin{tabular}{|c|c|c|c|c|}
\hline Shock Based On Industry & Horizon of Shock & Negative Shock & Neutral & Positive Shock \\
\hline \multirow[t]{4}{*}{ ROA } & \multirow[t]{2}{*}{1 year } & 0.002 & $0.043 * * *$ & $0.039 * * *$ \\
\hline & & $(0.014)$ & $(0.013)$ & $(0.013)$ \\
\hline & \multirow[t]{2}{*}{3 year } & $0.018^{*}$ & $0.043 * * *$ & $0.047 * * *$ \\
\hline & & $(0.010)$ & $(0.013)$ & $(0.014)$ \\
\hline \multirow[t]{4}{*}{ Sales Growth } & \multirow[t]{2}{*}{1 year } & $0.038 * *$ & $0.020 *$ & $0.030 * *$ \\
\hline & & $(0.016)$ & $(0.012)$ & $(0.014)$ \\
\hline & \multirow[t]{2}{*}{3 year } & $0.021^{*}$ & $0.025 *$ & $0.034 * * *$ \\
\hline & & $(0.012)$ & $(0.013)$ & $(0.013)$ \\
\hline \multirow[t]{4}{*}{ Employment Growth } & \multirow[t]{2}{*}{1 year } & $0.022 *$ & $0.024 *$ & $0.046^{* * *}$ \\
\hline & & $(0.013)$ & $(0.013)$ & $(0.014)$ \\
\hline & \multirow[t]{2}{*}{3 year } & $0.020^{*}$ & $0.038 * * *$ & $0.034 * *$ \\
\hline & & $(0.011)$ & $(0.012)$ & $(0.013)$ \\
\hline \multirow[t]{4}{*}{ Total Factor Productivity } & \multirow[t]{2}{*}{1 year } & $0.020^{*}$ & $0.029 * *$ & $0.024^{*}$ \\
\hline & & $(0.011)$ & $(0.014)$ & $(0.014)$ \\
\hline & \multirow[t]{2}{*}{3 year } & $0.029 *$ & 0.015 & $0.032 * *$ \\
\hline & & $(0.015)$ & $(0.016)$ & $(0.015)$ \\
\hline
\end{tabular}

Panel B: Coefficients of Regressing Investment Rate on the CEO Cycle Indicator

\begin{tabular}{|c|c|c|c|c|}
\hline Shock Based On Industry & Horizon of Shock & Negative Shock & Neutral & Positive Shock \\
\hline \multirow[t]{4}{*}{$\mathrm{ROA}$} & \multirow[t]{2}{*}{1 year } & $-0.046^{*}$ & $-0.045^{* *}$ & $-0.041^{*}$ \\
\hline & & $(0.027)$ & $(0.018)$ & $(0.022)$ \\
\hline & \multirow[t]{2}{*}{3 year } & $-0.097 * * *$ & $-0.033^{*}$ & $-0.023 *$ \\
\hline & & $(0.025)$ & $(0.018)$ & $(0.013)$ \\
\hline \multirow[t]{4}{*}{ Sales Growth } & \multirow[t]{2}{*}{1 year } & $-0.021 *$ & $-0.045 * *$ & $-0.058 * *$ \\
\hline & & $(0.013)$ & $(0.022)$ & $(0.024)$ \\
\hline & \multirow[t]{2}{*}{3 year } & $-0.073 *$ & -0.023 & $-0.071 * *$ \\
\hline & & $(0.038)$ & $(0.023)$ & $(0.036)$ \\
\hline \multirow[t]{4}{*}{ Employment Growth } & \multirow[t]{2}{*}{1 year } & $-0.042 *$ & $-0.050 * *$ & $-0.041^{*}$ \\
\hline & & $(0.022)$ & $(0.024)$ & $(0.023)$ \\
\hline & \multirow[t]{2}{*}{3 year } & $-0.075^{* * *}$ & $-0.035^{*}$ & $-0.045 * *$ \\
\hline & & $(0.026)$ & $(0.020)$ & $(0.022)$ \\
\hline \multirow[t]{4}{*}{ Total Factor Productivity } & \multirow[t]{2}{*}{1 year } & $-0.066^{*}$ & $-0.036^{*}$ & $-0.049 *$ \\
\hline & & $(0.037)$ & $(0.020)$ & $(0.028)$ \\
\hline & \multirow[t]{2}{*}{3 year } & $-0.052 *$ & $-0.055^{* *}$ & $-0.044 *$ \\
\hline & & $(0.030)$ & $(0.024)$ & $(0.023)$ \\
\hline
\end{tabular}

